\title{
An Informal Logic Bibliography
}

\author{
HANS.V. HANSEN University of Windsor
}

\section{Introduction}

In this bibliography I have tried to bring together and build on the work of others. In particular I have included material from (i) the bibliographies prepared by $\mathrm{R}$. H. Johnson and J. A. Blair for the three International Symposia on Informal Logic, (ii) Johnson and Blair (1980a), and (iii) Johnson and Blair (1985b). I have also incorporated material from (iv) Schmidt (1986b) and (v) Jensen (1989). I thank these authors for permission to borrow from their work.

Current research in informal logic is informed by work in argumentation theory, rhetoric, speech communication, and critical thinking. I have included entries from these fields which I think will be of interest to informal logicians. In adding to the earlier bibliographies I have followed the journals which take an interest in these matters and tried to keep abreast of new publications. It has been possible to verify by direct examination only about $85 \%$ of the entries.

The bibliography contains well over 900 entries. Not all of them have been indexed. Many of the entries touch on a variety of topics of interest to informal logicians but no entry has been indexed more than once. The index, like the bibliography itself, is therefore not claimed to be exhaustive. However, it is hoped that the index will prove useful for those with specific interests.

Informal Logic expects to publish an update to this bibliography in a future volume. We welcome corrections and suggestions.

I have had considerable help with this project. Michael F. Schmidt corrected several errors in an earlier version; J. Anthony Blair helped with the verification and the index. as well as providing invaluable advice; Robert C. Pinto gave expert assistance with the computer programme. I am grateful for the help so freely given.

In the interest of saving space the following abbreviations are used.
Arg. = Argumentation
$I L \quad=$ Informal Logic
ILN $=$ Informal Logic Newsletter
$J A F A=J$ ournal of the American Forensic Association
$P \& R=$ Philosophy and Rhetoric
$T P \quad=$ Teaching Philosophy
Q. = Quarterly $\quad J$ = Journal

\section{Bibliography}

Abate, Charies J. (1979). Fallaciousness and invalidity. $P \& R \quad 12,262-66$.

Acock, Malcolm (1985). Informal Logic Examples and Exercises. Belmont, CA: Wadsworth.

Adler, Jonathan (1982). Why be charitable? ILN $4: 2,15-16$.

Adler, Jonathan (1984). Abstraction is uncooperative. $J$, of the Theory of Social Behaviour 14 , $165-81$. (1987a). Alternatives, writing and the formulation of a thesis. IL $9,57-70$.

(1987b). Form, content and superstition. Teaching Thinking and Problem-Solving 9, $1-10$.

(1987c). On resistance to critical thinking. In D. N. Perkins, J. Lockheed and J. Bishop (eds.), Thinking: The Second International Conference (Hillsdale, NJ: Lawrence Erlbaum), 247-60. 
Adler, Jonathan (1989). Epistemics and the total evidence requirement. Philosophia 19, 227-42.

(1990a). Conservatism and tacit confirmation. Mind 99, 1-14.

(1990b). Double standards, equality, and the right reference class. $J$. of Applied Philosophy 7, 215-27.

Allen, Derek (1988). Inferential soundness. IL 10, 57-65.

(1990). Trudy Govier's Problems in Argument Analysis and Evaluation. IL 12, 43-62.

Anderson, Jerry M. and Paul J. Dovre (eds.) (1968). Readings in Argumentation. Boston: Allyn and Bacon.

Anderson, Ray Lynn and David C. Mortensen (1967). Logic and marketplace argumentation. Quarterly J. of Speech 53, 143-51.

Angell, Richard B. (1964). Reasoning and Logic. New York, NY: Appleton Century Crofts.

Annis, David B. (1974). Techniques of Critical Reasoning. Columbus, $\mathrm{OH}$ : Charles E. Merrill.

and Linda Annis (1979). Does philosophy improve critical thinking? TP 3 , $145-52$.

Annis, Linda and David B. Annis (1984). McPeck on critical thinking: A reply, IL 6, 42-44.

Apostel, Leo (1971). Assertion logic and the theory of argumentation. $P \& R \quad 4,92-110$.

(1979). What is the force of an argument? Revue International de Philosophie 33, $99-109$.

(1982). Toward a general theory of argumentation. In Barth and Martens (1982), 93-122.

Apotheloz, Denis (1987). Logical and non-logical foundations of argumentation. In van Eemeren, Grootendorst et al. $(1987 \mathrm{c}), 407-17$.

Arnold, Carroll C. (1986). Implications of Perelman's theory of argumentation. In James Golden and Joseph J. Pilotta (eds.), Practical Reasoning in Human Affairs: Studies in Honor of Chaim Perelman (Dordrecht: Reidel).

(1987). Johnstone's 'wedge' and the theory of rhetoric. $P \& R 20,118-128$.

Aune, Bruce (1986). Formal logic and practical reasoning. Theory and Decision 20, 301-20.
Bach, Kent (1984). Default reasoning: Jumping to conclusions and knowing when to think twice. Pacific Philosophical Quarterly 65, 37-58.

Bailin, Sharon (1987). Critical and creative thinking. $I L 9,23-30$.

(1987). Moral and aesthetic argumentation. In van Eeemeren and Grootendorst (1987b), 178-86.

(1988). Achieving Extraordinary Ends: An Essay in Creativity. Dordrecht: Kluwer.

(1989) Belief, doubt and critical thinking: Reconciling the contraries. Philosophy of Education: Proceedings 45, 315-19.

Balthrop, V. William (1980). Argument as linguistic opportunity: A search for form and function. In Jack Rhodes and Sara Newell (eds.), Proceedings of the Summer Conference on Argumentation (Salt Lake City: SCA/AFA).

Bandman, Elsie L. and Bertram Bandman (1988). Critical Thinking in Nursing. Norwalk, CT: Appleton and Lange.

Bar-Hillel, Yehoshua (1964). More on the fallacy of composition. Mind 73, 125-6.

Barker, Evelyn M. (1981). Everyday Reasoning. Englewood Cliffs, NJ: Prentice-Hall

(1989). Beardsley's theory of analogy. IL $11,185-94$.

Barker, John A. (1976). The fallacy of begging the question. Dialogue 15, 241-55.

Barker, Stephen F. (1974). The Elements of Logic (2nd ed.). New York: McGraw Hill. 1st edition 1965.

(1989). Reasoning by analogy in Hume's Dialogues. IL 11, 173-84

Barry, Vincent E. (1983). Good Reason for Writing. Belmont, CA: Wadsworth.

and Joel Rudinow (1990). Invitation to Critical Thinking. New York: Holt, Rinehart and Winston. Ist edition 1984.

Barry, Vincent E. and Douglas J. Soccio (1980). Practical Logic (3rd ed.). New York: Holt, Rinehart and Winston. 1st edition 1976.

Barth, E. M. (1985a). A new field of empirical logic: Bioprograms, logemes and logics as institutions. Synthese 63, 375-88.

(1985b). Philosophical logic in the Netherlands after 1940. Ruch Filozoficzny 42, 175-205.

$(1985 \mathrm{c})$. Two-phase epistemology and models of dialogue logic. Philosophica 35, 69-88. 
Barth, E. M. (1987). Logic to some purpose: Theses against the deductive-nomological paradigm in the science of logic. In van Eemeren, Grootendorst, et al. (1987a), 33-45.

(1990). In the service of human society: Formal, informal or anti-logical? The philosophy of the logician E. W. Beth. IL 12, 1-10.

and Erik C. W. Krabbe (1982). From Axiom to Dialogue: A Philosohical Study of Logics and Argumentation. Berlin: Walter de Gruyter.

Barth, E, M. and J. L. Martins (1977). Argumentum ad hominem: From chaos to formal dialectic. Logique et Analyse 20, 76-96.

(1982). Argumentation: Approaches to Theory Formation. Amsterdam: John Benjamins.

Basu, Dilip K. (1986). A question of begging. IL $8,19-26$.

Bator, Paul G. (1988). The 'good reasons' movement: A confounding of dialectic and rhetoric? $P \& R$ 21, 38-47.

Battersby, Mark E. (1989). Critical thinking as applied epistemology. IL 11, 91-99.

Beardsley, Monroe C. (1950), Practical Logic. Englewood Cliffs, NJ: Prentice-Hall.

(1975). Thinking Straight: Principles of Reasoning for Readers and Writers (4th ed.). Englewood Cliffs, NJ: Prentice-Hall. 2nd edition 1956 249-60

(1981). Logic and rhetoric. TP 4.

Belnap, Nuel D, Jr. (1981). Logica Docens and relevance. $T P 4,419-27$.

Bendegem, Jean Paul van (1985). Dialogue logic and problem solving. Philosophica 25, 113-34.

Benoit, Pamela J. (1983). Extended arguments in children's discourse. JAFA 20, 72-89.

(1989). Relationship arguments: An interactionist elaboration of speech acts. Arg. $3,423-37$.

Benoit, William L. (1987). Argumentation and credibility appeals in persuasion. Southern Speech Communication J. 52, 181-97.

and Vincent F. Follert (1986). Graduate courses in argumentation theory. Communicafion Education 35, 61-66.

Berg, Jonathan (1987). Interpreting arguments. IL 9, 13-20. See also 9.2\&3, Errata, 152.
Bernstein, David (1990). A problem solving interpretation of argument analysis. IL $12,79-85$.

Berriman, William (1980). Review of Giere's Understanding Scientific Reasoning. ILN 2:2, 15-17.

Beyer, Barry K. (1987). Practical Strategies for the Teaching of Thinking. Boston: Allyn and Bacon.

Bickenbach, Jerome E. (1979). Justifying deduction. Dialogue 18, 500-16.

(1982). The diversity of proof. ILN 4:2, $7-12$

(1990). The 'artificial reason' of the law. IL 12, 23-32.

Billig, Michael (1987) Arguing and Thinking: A Rhetorical Approach to Social Psychology. Cambridge: Cambridge Unjversity Press.

Binker, A. J. A. and Marla Charbonneau (1983). Piagetian insights and teaching critical thinking. ILN 5:2, 10-15.

Binkley, Robert W. (1980). Can the ability to reason well be taught? In Blair and Johnson (1980), 79-92.

(1981). A system of rational appraisal. ILN 4:1, 7-10.

Biro, J, I. (1977). Rescuing 'begging the question'. Metaphilosophy 8, 257-71.

(1984). Knowability, believability and begging the question: A reply to Sanford. Metaphilosophy 15, 239-247.

(1987). A sketch of an epistemic theory of fallacies. In van Eemeren, Grootendorst et al. (1987b), 65-73.

Black, Max (1949). Vagueness: An exercise in logical analysis. In Language and Philosophy (Ithaca, NY: Cornell University Press), chapt. 2

(1955). Critical Thinking. New York: Prentice-Hall. 1st edition 1946.

(1963). Reasoning with loose concepts. Dialogue 2, 1-12.

Blair, J. Anthony (1984). Teaching argument in critical thinking. The Community College Humanities Review 5, 19-30.

(1985). Some challenges for critical thinking. In Hoaglund (1985), 69-82.

(1986a). Comments on Frans van Eemeren: 'Dialectical analysis as a normative reconstruction of argumentative discourse". Text 6, 17-24. 
Blair, J. Anthony (1986b). The Keegstra affair: A test case for critical thinking. The History and Social Science Teacher 21, 158-64.

(1987a). Recent developments in critical thinking in anglophone North America. Thinking 7, 2-11.

(1987b). Argumentation, inquiry and speech act theory. In van Eemeren, Grootendorst et al. (1987a), 189-99.

$(1987 \mathrm{c})$. Critical thinking perspectives: Recent developments in anglophone North America. Thinking 7, 2-6.

(1987d). Everyday argumentation from an informal logic perspective. In Wenzel (1987a), 177-83.

(1988a). Argumentation and informal fallacies. In Venant Cauchy (ed.), Philosophie et Culture, 5 (Montreal: Editions Montmorency), 381-84.

(1988b). Current issues in informal logic and critical thinking. In A. Fisher (1988a), 15-29.

(1988c). Teaching informal logic using Logical Self-Defonse. In Fisher (1988a), 60-64.

(1988d). What is bias? In Govier (1988c), 93-103.

(1989). Premise relevance. In Maier (1989), 67-84.

(1990). Fallacies in everyday argument. In Trapp et al. (1990), 121-33.

Blair, J. Anthony and Ralph H. Johnson (eds.) (1980). Informal Logic: The First International Symposium. Inverness, CA: Edgepress.

(1987a). Argumentation as dialectical Arg. 1, 41-56.

(1987b). The current state of informal logic and critical thinking. IL 9, 147-51.

(1989). Informal logic: A thematic account. In Maimon (1989), 93-110.

Blythin, Evan (1979). Arguers as lovers: A dialectical perspective. $P \& R 12,176-86$.

Bomstad, Linda and Perry Weddle (1989). North American perspectives on teaching critical thinking: A general bibliography. Arg. 3, 237-42.

Bouchard, Guy (1981), L'antimodele platonicien de la nouvelle rhetorique. Canadian $J$. of Philosophy 11, 693-711.
Bowles, George (1989a). Favorable relevance and arguments. IL 11, 11-17.

(1989b). Professor Kasachkoff on explaining and justifying. IL 11, 107-10. $65-77$

Boylan, Michael (1988). The Process of Argument. Englewood Cliffs, NJ: Prentice-Hall.

Braaten, Jane (1987). Rational consensual procedure: Argumentation or weighted inquiry. Synthese 71, 347-54.

Bradie, Michael and Kenneth Sayre (eds.) (1981). Reasons and Decision. 3. Bowling Green: Bowling Green Studies in Applied Philosophy.

Brandon, E. P. (1983). Argument Analysis. Kingston, Jamaica: University of West Indies. (1986). Ellipsis. It 8, 93-103.

(1987). Deductive reasoning ability, error, and education. In van Eemeren and Grootendorst et al. (1987c), 155-61.

Brinton, Alan (1981). Logic and the liberal arts curriculum. Liberal Education 67, 254-60.

(1985). A thetorical view of the ad hominem. Australasian I. of Philosophy 63 . 50-63.

(1986). Ethotic arguments. History of Philosophy Q. 3, 245-58.

(1987). Ethotetic arguments: Some uses. In van Eemeren, Grootendorst et al. (1987c), 246-54,

(1988a). Appeal to the angry emotions. IL $10,77-87$.

(1988b). Pathos and the "appeal to emotion': An Aristotelian analysis. History of Philosophy Q. 5, 207-19.

Broad, C. D. (1950). Some common fallacies in political thinking. Philosophy 25, 99-113.

Brockriede, Wayne (1960). Toulmin on argument: An examination and aplication. Quarterly $J$ of Speech 46, 44-53.

$1-11$.

(1972). Arguers as lovers. $P \& R 5$, $179-82$.

(1975). Where is argument? JAFA 11 ,

(1977). Characteristics of arguments and arguing. JAFA 13, 129-32. 
Brockriede, Wayne (1985). Constructs, experience and argument. Quarterly $J$, of Speech 71, 151-63.

Brod, Harry (1982). Logic as politics. TP 5, 211-19.

Brown, Robert (1970). The burden of proof. American Philosphical Q. 7, 74-82.

Brown, William R. (1987). The holographic view of argument. Arg. 1, 89-102.

\section{1, $161-172$.}

(1989). Two traditions of analogy. $I L$

Browne, M. Neil and Stuart M. Keeley (1986). Asking the Right Questions: A Guide to Critical Thinking (2nd ed.). Englewood Cliffs, NI: Prentice-Hall. 1st edition 1981.

Broyles, James E. (1975). The fallacies of composition and division. P\&R 8, 108-13.

Bruner, Michael S. (1983). Argument from a pragmatic perspective. JAFA 20, 90-97.

Brutian, Georg (1984). Argumentation. Yerevan.

Burbidge, John (1990). Within Reason: A Guide to Non-Deductive Reasoning. Peterborough, Ont.: Broadview.

Burke, Michael (1985). Unstated premises. IL 7, 107-18.

Burke, Richard J. (1984). A rhetorical conception of rationality. IL 6, 17-25.

Burleson, Brant R. (1979). On the analysis and criticisms of arguments: Some theoretical and methodological consideratons. JAFA 15, 137-47.

Campbell, Stephen K. (1974). Flaws and Fallacies in Statistical Thinking. Englewood Cliffs, NJ: Prentice-Hall.

Capaldi, Nicholas (1973). The Ant of Deception. Buffalo: Prometheus Books. Published by D. W. Brown, New York, 1971.

Carey, Stephen H. (1988). Upsetters. IL 10,97-103.

Carlson, Laurie (1983). Dialogue Games: An Approach to Discourse Analysis. Dordrecht: Reidel.

Carney, James D, and Richard K. Scheer (1980). Fundamentals of Logic ( $3 \mathrm{rd}$ ed.). New York: Macmillan. 1st edition 1964.

Carroll, Robert T. (1983). A comment on fallacies and argument analysis. ILN 5:2, 22-23.
Carson, A. S. (1980). Review of Scriven's Reasoning. ILN 2:2, 17-19.

Castaneda, Hector Neri (1960). On a proposed revolution in logic. Philosophy of Science 27, $279-92$

Cederblom, Jerry and David Paulsen (1988). Making reasonable decisions as an amateur in a world of experts. In Govier (1988c), 138-49.

(1991). Critical Reasoning (3rd ed.). Belmont, CA: Wadsworth Publishing Co. 1st edition 1982.

Chaffee, John (1985). Thinking Critically. Boston: Houghton Mifflin.

Champaud, Christian and Dominique Bassano (1987). Argumentation and child development: A general bibliography. Arg. 1, $201-07$.

Church, Russell T. (1979). A bibliography of argumentation and debate for 1975-76. JAFA $15,228-43$.

and David C. Buckley (1983). Argumentation and debating propositions of value: A bibliography. JAFA 19, 239-50.

Cizek, F. (1974). The problem of fallacies. Teorie A Metoda 6, 101-15.

Clemens, David (1985). Technoethics. IL 7, 163-65.

Cohen, L. Jonathan (1982). Are people programmed to commit fallacies? J. for the Theory of Social Behaviour 12, 251-74.

Cohen, Maurice (1977). Contextual analysis: An approach to the study of philosophic arguments. Metaphilosophy 8, 3-20.

Cole, Richard (1965). A note on informal fallacies. Mind 74, 432-33.

Colwell, Gary (1989). God, the Bible and circularity. IL 11,61-73.

Conklin, Forrest (1968). A bibliography of argumentation and debate for 1967. JAFA 5, 85-94.

(1970). A bibliography of argumentation and debate for 1969. JAFA 7, 134-58.

(1971). A bibliography of argumentation and debate for 1970. JAFA 8, 81-104.

Conley, Thomas M. (1984). The enthymeme in perspective. Quarterly J. of Speech 70, 168-87.

Cooley, J. C. (1959). On Mr. Toulmin's revolution in logic. J, of Philosophy 56, 297-319.

Copi, Irving M. (1986). Informal Logic. New York: Macmillan. 
Copi, Irving $M$. and Carl Cohen (1990). Introduction to Logic (8th. ed.). New York: Macmillan. 1st edition 1953.

Corcoran, John (1989). Argumentations and logic. Arg. 3, 17-43.

Corgan, Verna C, (1987). Perelman's universal audience as critical tool. JAFA 23, 147-57.

Corliss, Richard (1972). A theory of contextual implication. P\&R 5, 215-30.

Costa, Arthur and Lawrence F. Lowery (1989). Techniques for Teaching Thinking. Pacific Grove, CA: Midwest Publications.

Couch, Dan (1981). Improving reasoning skills. Thinking 3, 38-9.

Covey, Preston (1981a). Formal logic and philosophic analysis. TP 4, 277-302.

(1981b). Logic and liberal learning: Some salient issues. TP 4, 207-30.

Cowan, Joseph L. (1964). The Uses of Argument-an apology for logic. Mind 73, 27-45.

(1969). The gambler's fallacy. Philosophy and Phenomenological Research 30, 238-51.

Cox, J. Robert, Malcolm Sillars and Gregg B. Walker (eds.) (1985). Argument and Social Practice: Proceedings of the Fourth SCA/AFA Conference on Argumentation. Annandale, VA: Speech Communication Association.

Cox, J. Robert and Charles Willard (eds.) (1982). Advances in Argumentation Theory and Research. Carbondale: Southern Illinois University Press.

Crable, Richard E. (1976a) Argumentation as Communication: Reasoning With Receivers. Columbus, $\mathrm{OH}$ : Charles E. Merrill.

Crable, Richard E. (1976b). Models of argumentation and judicial judgment. JAFA 12, 113-20.

Cragan, John F. and Craig W. Cutbirth (1984). A revisionist perspective on political ad hominem argument: A case study, Central States Speech J. 35, 228-237.

Crimmel, Henry H. (1980). Logic as a liberal art. Liberal Education 66, 377-81.

(1981). A reply to Professor Brinton. Liberal Education 67, 261-62.

Crossley, David J. and Peter A. Wilson (1979). How to Argue: An Introduction to Logical Thinking. New York: Random House.
Cureton, Robert D. (1973). A bibliography for argumentation and debate for 1973.JAFA 13 . 197-206.

d'Angelo, Edward (1974). The concept of critical thinking. Revolutionary World 9, 49-55.

Damer, T. Edward (1987). Attacking Faulty Reasoning (2nd ed.), Belmont, CA: Wadsworth. 1st edition 1980 .

Damme, F. van (1984). Towards more natural dialogue logics as a more natural dialogue system. Logique et analyse 116, 409-19.

Davson-Galle, Peter (1989) Interpreting arguments and judging issues. IL 11, 41-45.

Dayton, Eric B. (1981). Persuasive arguments and disagreements of principle. Canadian $J$. of Philosophy 11, 741-49.

Dewey, John (1982). Logic: The Theory of Inquiry. New York: Holt, Rinehart and Winston. Reproduction of 1938 edition published by Irivington, NY.

Dolan, John M. (1988). Consent as a commodity. IL 10, 177-94. Review of Herman and Chomsky"s Manufacturing Consent.

Donn, Mike (1990) Help in finding missing premises. TP $13,159-64$.

Doss, Seale (1985). Three steps towards a theory of informal logic. IL 7, 127-135.

(1987). Elementary Logic for Philosophy Students. Ripon, WI: Ripon College Press.

(1989). Who needs a theory of informal logic? IL 11, 111-18.

Eemeren, Frans H. van (1986). Dialectical analysis as normative reconstruction of argumentative discourse. Text 6, 1-16.

(1987a). Argumentation studies" five estates. In Wenzel et al. (1987a), 9-24.

(1987b). For reasons sake: Maximal argumentative analysis of discourse. In van Eemeren, Grootendorst, et al. (1987a), 201-15.

(1988). Argumentation analysis: A Dutch counter-balance. In Fisher (1988a), 39-53.

Eemeren, Frans $H$. van and Rob Grootendorst (1982a). The speech acts of arguing and convincing in externalized discussions. $J$. of Pragmatics 6, 1-24.

(1982b). Unexpressed premises: Part I. JAFA $19,97-106$ 
Eemeren, Frans H. van and Rob Grootendorst (1983). Unexpressed premises: Part II. JAFA $19,215-25$.

(1984). Speech Acts in Argumentative Discussion. Dordrecht: Foris.

(1987a). Fallacies in pragma-dialectical perspective. Arg. 1, 283-301.

(1987b). Teaching argumentation analysis and critical thinking in the Netherlands. IL 9, 57-69.

(1988a). Rationale for a pragmadialectical perspective. Arg. 2, 271-91.

(1988b), Rules for argumentation in dialogues. Arg. 2, 499-510.

(1989a). A pragma-dialectical perspective on norms. In Maier (1989), 97-112.

(1989b). A transition stage in the theory of fallacies. $J$. of Pragmatics 13, 99-109.

$(1989 \mathrm{c})$. Speech act conditions as tools for reconstructing argumentative discourse. Arg. 3, 367-83.

(1989d). Writing argumentative texts. From analysis to presentation: A pragmadialectical appoach. In Gronbeck 1987, 324-30.

Eemeren, Frans H. van, Rob Grootendorst, J. Anthony Blair and Charles Willard (1987a). Argumentation: Across the Lines of Discipline. Dordrecht: Foris.

(1987b). Argumentation: Analysis and Practices. Dordrecht: Foris.

(1987c). Argumentation: Perspectives and Approaches. Dordrecht: Foris.

Eemeren, Frans H. van, Rob Grootendorst and Bert Meuffels (1989). The skill of identifying argumentation. JAFA 25, 239-45.

Eemeren, Frans H. van, Rob Grootendorst and Tjark Kruiger (1984). The Study of Argumentation. New York: Irvington.

(1987). Handbook of Argumentation Theory: A Critical Survey of Classical Backgrounds and Modem Studies. Dordrecht: Foris.

Eemeren, Frans H. van and Tjark Kruiger (1987). Identifying argument schemes. In van Eemeren, Grootendorst et al, $(1987 \mathrm{c}), 70-81$.

Ehninger, Douglas (1970). Argument as method: Its nature, its limitations, and its uses. Conmmunication Studies 37, 101-10.
(1974). Influence, Belief, and Argument, An Introduction to Reponsible Persuasion. Glenview, IL: Seott, Foresman and Co.

(1980). Toward a taxonomy of prescriptive discourse. In Eugene White (ed.), Rhetoric in Transition (University Park, PA: Stage University Press).

Eisenberg, Ann R. (1987). Learning to argue with parents and peers. Arg. 1, 113-25.

Engel, S. Morris (1980). Analyzing Informa! Fallacies. Englewood Cliffs, NJ: Prentice-Hall.

(1984). The Language Trap, or How to Defend Yourself Against the Tyranny of Words. Englewood Cliffs, NJ: Prentice-Hall.

(1985). With Good Reason: An Introduction to Informal Fallacies ( $3 r d$ ed.). New York: St. Martin's. Ist edition 1976.

(1986a). Explaining equivocation. Metaphilosophy 17, 192-99.

(1986b). Fallacy, wit and madness. P\&R 19, 224-241.

(1986c). Wittgenstein's theory of fallacy. $I L 8,67-80$.

Engelbretsen, George (1973). Review of Hamblin's Fallacies, Dialogue 12, 151-54.

(1984). Freeman on induction/ deduction. IL $6,26-27$.

Ennis, Robert H. (1958). An appraisal of the Watson-Glaser critical thinking appraisal. J. of Educational Research 52, 155-58.

(1962). A concept of critical thinking. Harvard Educational Review 32, 81-111.

(1964). Operational definitions. American Educational Research J. 1, 183-201. (1969a). Logic in Teaching. Englewood Cliffs, NJ: Prentice-Hall.

(1969b). Ordinary Logic. Englewood Cliffs, NJ: Prentice-Hall. Available from IIlinois Critical Thinking Project.

(1974). The believability of people. Educational Forum 39, 347-54.

(1979). A conception of rational thinking. Philosophy of Education: Proceedings 35, 3-30.

(1980). Eight fallacies in Bloom's taxonomy. Philosophy of Education: Proceedings $36,269-73$. 
Ennis, Robert H. (1981a). A conception of deductive logic competence. TP 4, 337-85

(1981b). Logic and critical thinking. Philosophy of Education: Proceedings 37, 228-32.

(1981c). Rational thinking and educational practice. In Jonas F. Soltis (ed.), Philosophy and Education 80th Yearbook, NSSE (Chicago: University of Chicago Press), 143-83.

(1982). Identifying implicit assumptions. Synthese 51, 61-86.

(1984). Problems in testing informal logic/critical thinking/reasoning. IL 6, 3-9.

(1985). A concept of critical thinking. In Hoaglund (1985), 13-40.

(1987a). A bibliography on testing in critical thinking. CT News $6: 1,7$.

(1987b). A taxonomy of critical thinking dispositions and abilities. In J. Baron and R. L. Sternberg (eds.), Teaching Thinking Skills: Theory and Practice (New York: W. H. Freeman).

$(1987 \mathrm{c})$. Testing teachers' competence, including their critical thinking abilities. Philosophy of Education: Proceedings 43, 413-20.

(1989a). Critical thinking and subject specificity. Educational Researcher 18, 4-10.

(1989b) The rationality of rationality: Why think critically? Philosophy of Education: Proceedings 45, 402-05.

Evra, James van (1985). Logic, the liberal science. TP 8, 285-94.

Facione, Peter A. (1976). Counterexamples and where they lead. Philosophy and Phenomenological Research 36, 523-30.

(1984) Toward a theory of CT, Liberal Education 70, 253-61.

(1986) Testing college level CT. Liberal Education 72, 221-31. $211-17$

(1987). Teaching about fallacies. $T P 10$,

(1989) Assessing inference skills. Newark, DE: ERIC Clearinghouse on Educational Tests, Measurement and Evaluation.

(1990a) Critical thinking: A statement of expert consensus for purposes of educational assessment and instruction. Newark, DE: ERIC Clearinghouse on Tests, Measurement, and Evaluation.

(1990b). Thirty great ways to mess up a ciritical thinking test. $I L 12,106-12$. and Donald Scherer (1978). Logic and Logical Thinking. New York: McGraw Hill.

Fahnestock, Jeanne and Marie Secor (1982), A Rhetoric of Argument. New York: Random House.

Fair, Frank (1973). The fallacy of many questions: Or how to stop beating your wife. Southwestern $J$. of Philosophy 4, 89-92.

Farrell, Thomas B. (1977). Validity and rationality: The rhetorical constitutents of argumentative form. JAFA 13, 142-49.

Fearnside, W. Ward (1980). About Thinking. Englewood Cliffs, NJ: Prentice-Hall.

and William B. Holther (1959).

Fallacy: The Counterfeit of Argument, Englewood Cliffs, NI: Prentice-Hall.

Feteris, Eveline T, (1990). Conditions and rules for rational discusssion in a legal process: $A$ pragma-dialectical perspective. Argumentation and Advocacy 26, 108-17.

Feuer, Lewis S. (1983). The genetic fallacy reexamined. In Paul Kurtz (ed.), Sidney Hook: Philosopher of Democracy and Humanism (Buffalo, NY: Prometheus Books), 227-246.

Finocchiaro, Maurice A. (1974). The concept of ad hominem argument in Galileo and Locke. Philosophical Forum 5, 394-404.

(1979a). The Logical Structure of Galileo's Dialogue: A case study in applied logic. Logique et Analyse 22, 159-80.

(1979b). The psychological explanation of reasoning: Logical and methodological problems. Philosophy of the Social Sciences 9, $277-91$.

(1980). Galileo and the Art of Reasoning: Rhetorical Foundations of Logic and Scientific Method. Dordrecht: D. Reidel Publishing Co.

(1981). Fallacies and the evaluation of reasoning. American Philosophical Q. 18, 13-22.

(1984). Informal logic and the theory of reasoning. IL $6,3-8$.

(1987a). An historical approach to the study of argumentation. In van Eemeren, Grootendorst, et al. (1987a), 81-91.

(1987b). Six types of fallaciousness: Toward a realistic theory of logical criticism. Arg. 1, 263-82.

(1988a). A multi-dimensional course in critical thinking. CT News 7:2, 1, 4-6. 
Finocchiaro, Maurice A. (1988b). Dialectic and argument in philosophy: A case study of Hegel's Phenomenological preface. Arg. 2, 175-90.

(1988c). Empiricism, judgment and argument: Toward an informal logic of science. Arg. 2, 313-35.

Fischer, David H. (1970). Historians' Fallacies: Toward a Logic of Historical Thought. New York: Harper and Row.

Fisher, Alec (1986). Informal logic at the University of East Anglia. CT News 4:4, 1 \& 4 .

(1987). Using assertability conditions to extract and evaluate arguments. In van Eemeren, Grootendorst, et al. (1987b), 25-33.

(ed.) (1988a). Critical Thinking: Proceedings of the First British Conference on Informal Logic and Critical Thinking. Norwich: University of East Anglia.

(1988b). The Logic of Real Arguments. Cambridge: Cambridge University Press.

(1989). Suppositions in argumentation. Arg. 3, 40l-13.

Fisher, Walter R. (1978). Toward a logic of good reasons. Quarterly J. of Speech 64, 376-84.

(1987). Technical logic, rhetorical logic, and narrative rationality. Arg. 1, 3-21.

(1980). Rationality and the logic of good reasons. $P \& R \quad 13,121-30$.

Flesch, Rudolf (1951). The Art of Clear Thinking. New York, NY: Harper and Row.

Flew, Antony (1977). Thinking Straight. Buffalo, NY: Prometheus Books. Published by Fontana, Great Britain, 1975, as Thinking About Thinking.

Fogelin, Robert J. (1983). Charitable reconstruction and logical neutrality. $\operatorname{ILN} 4: 3,2-5$. (1985). The logic of deep disagreements. IL 7, 1-8.

(1987). Understanding Arguments, An Introduction to Informal Logic (3rd ed.). San Diego, CA: Harcourt, Brace, Johanovich. Ist edition 1978 .

(1989). A brief treatise in epistemic economics. CT News 7:5, 1, 5-6.

Fallacies, Arg. 1, 255-62.

Fohr, Samuel D. (1980a). The deductive-inductive distinction. ILN 2:2, 5-8.

(1980b). Deductive-inductive: Reply to criticisms. ILN 3:1, 5-10.
Follert, Vincent (1981). Risk analysis: Its application to argumentation and decision-making. JAFA 18, 99-108.

Follman, John (1987). Teaching critical thinking/ thinking--Promises! Promises! IL 9, 13140.

Foss, Sonja K, Karen A. Foss and Robert Trapp (1985). Contemporary Perspectives on Rhetoric. Prospect Heights, IL: Waveland Press.

Freeman, David Hugh (1967), Logic: The Art of Reasoning. New York: David McKay.

Freeman, James B. (1983). Logical form, probability interpretations, and the inductivedeductive distinction. ILN 5:2, 2-10.

. (1984). Reply to Englebretsen. IL 6, $34-40$.

(1985). Dialectical situations and argument analysis. IL 7, 151-62.

(1987). Review of Handbook of Argumentation Theory by'van Eemeren et al. IL 9, 49-51.

(1988), Thinking Logically: Basic Concepts for Reasoning. Englewood Cliffs, NJ: Prentice-Hall.

(1989) The human image system and thinking critically in the strong sense. IL 11 , $19-40$.

(1990). Walton's Informal Logic: A Handbook for Critical Argumentation. IL 12 , 87-105.

Fuller, Steve and Charles A. Willard (1987). In defense of relativism: Rescuing incommensurability from the self-excepting fallacy. In van Eemeren, Grootendorst et al. (1987c), 313-20.

Furlong, John (1987). Rationality, cognitive science, and the theory of argumentation. In van Eemeren, Grootendorst et al. (1987c), 357-63.

Galle, Peter (1981). Another note on the 'surprise test' puzzle. ILN 3:3, 21-22.

Garver, Eugene (1978). Rhetoric and essentially contested arguments. $P \& R 11,156-72$.

(1985). Teaching critical thinking as a discipline. IL 7, 166-68.

(1987). Arguing over incommensurable values. In van Eemeren and Grootendorst (1987b), 163-69.

Gasser, James (1987). Argumentation in proof. In van Eemeren, Grootendorst et al. $(1987 \mathrm{c})$, $321-26$. 
Gauker, Christopher (1986). The principle of charity. Synthese 69, 1-25.

Geach, Peter (1976). Reason and Argument. Oxford: Basil Blackwell.

Gelber, Hester Goodenough (1987). The fallacy of accident and the dictum de omni. Vivarium $25,110-45$.

Gensier, Harry J. (1989). Logic: Analysing and Appraising Arguments. Englewood Cliffs, NJ: Prentice-Hall.

George, Rolf (1983a). A postscript on fallacies. $J$. of Philosophical Logic 12, 319-25.

(1983b). Bolzano's consequence, relevance, and enthymemes. $J$. of Philosophical Logic 12, 299-318.

Gerber, D. (1974). On argumentum ad hominem. The Personalist 55, 23-29.

(1977). Reply to Woods and Walton's 'Ad hominem, contra Gerber'. The Personalist 58, 145-46.

Gibbs, Leonard (1985). Teaching critical thinking at the university level. IL $7,137-49$

Giere, Ronald N. (1979). Understanding Scientific Reasoning. New York: Holt, Rinehart and Winston.

Gilbert, Michael A. (1979). How to Win an Argument. New York: McGraw-Hill.

Girle, Roderic A. (1988). Reasoning with both formal and informal logic. IL $10,51-54$

Golden, James L. (1987). Douglas Ehninger's philosophy of argument. In McKerrow 1982, $23-40$.

and Josina M. Makau (1982). Perspectives on judicial reasoning. In McKerrow (1982), 157.77

Goldman, Alan (1987). The force of precedent on legal, moral and empirical reasoning. Synthese $71,323-346$

Goldstein, Laurence (1988). Logic and reasoning. Erkenntnis 28, 297-320.

Good, I. J. (1959). A classification of fallacious arguments and interpretations. Methodos 11 , $147-59$.

Goode, Terry M. and John Wettersten (1982). How do we learn from arguments? Toward an account. Canadian J. of Philosophy 12,673-89.
Goodnight, G. Thomas (1989). Toward a social theory of argument. Argument and Advocacy $26,60-70$.

Goodwin, Paul D. and Joseph W. Wenzel (1979). Proverbs and practical reasoning: A study in socio-logic. Quarterly $I$. of Speech 65 , 289-302.

Gordon. Donald R. (1966). Language, Logic and the Mass Media. Toronto: Holt, Rinehart and Winston.

Goudge, T. A. (1961). The genetic fallacy. Synthese 13, 41-48.

Gough, James and Christopher Tindale (1985). 'Hidden' or 'missing' premises. IL 7, 99-106.

Goulding, Daniel J. (1965). Aristotle's concept of the enthymeme. JAFA 2, 104-08.

Govier, Trudy (1980a). Review of Wellman's Challenge and Response. ILN 2:2, 10-15.

(1980b). Assessing arguments: What range of standards? ILN 3:1, 2-4.

$(1980 \mathrm{c})$. More on deductive and inductive arguments. ILN 2:3, 7-8.

(1981a). Rigour and reality. Queen's Quarterly 88, 525-35.

(1981b). Uncharitable thoughts about charity. ILN 4:1, 5-6.

(198/c). Worries about tu quoque as a fallacy. ILN 3:3,2-4.

(1982a). What's wrong with slippery slope arguments? Canadian I. of Philosophy 12, $303-16$

(1982b). Who says there are no fallacies? ILN 5:1, 2-10.

(1983a). Ad hominem: Revising the textbooks. TP $6,13-24$.

(1983b). Critical review of McPeck's: Critical Thinking and Education. Dialogue 22. 170-75

$10-11$.

(1983c). On Adler on charity. ILN 4:3,

(1985). Logical analogies. IL 7, 27-33

(1987a). Beyond induction and deduction. In van Eemeren, Grootendorst, et al. (1987a), 57-64. 
Govier, Trudy (1987b). Problems in Argument Analysis and Evaluation. Dordrecht: Foris.

(1988a). A Practical Study of Argument (2nd ed.). Belmont, CA: Wadsworth. 1st edition 1985.

(1988b). A practical study of argument. In A. Fisher (1988a), 54-59.

(1988c). Selected Issues in Logic and Communication. Belmont, CA: Wadsworth.

(1988d). Tu quoque, credibility and argument. ISSA Newsletter 3, 2-13.

(1988e). Ways of teaching reasoning directly, In A. Fisher (1988a), 30-38.

(1989a). Analogies and missing premises. IL 11, 141-52.

(1989b). Critical thinking as argument analysis'? Arg. 3, 115-26.

Grable, Richard E. (1976). Argumentation as Communication: Reasoning with Receivers. Columbus, OH: Charles E. Merrill.

Gratton, Claude (1990). Review of Perelman's Rhetorique. IL 12, 117-20.

Grennan, Wayne (1984), Argument Evaluation. Lanham, MD: University Press of America.

(1986). A 'logical audit' seheme for two-premise arguments. IL 8, 125-32.

(1987). Review of Copi's Informal Logic. IL 9. 50-51.

Griffin, Nicholas (1981a). Charity begins much earlier than supposed. ILN 4:1,6.

(1981b). Review of Baum Ethical Arguments for Analysis and Engel Analysing Informal Fallacies. ILN 3:3, 20-21.

Griffin-Collart, Evelyne (1979). L'argumentation et la raisonable dans une philosophie du sense commun. Revue International de Philosophic 33, 202-15.

Griffith, William B. (1975). Symbolic logic and the appraisal of arguments. $T P$ 1, 13-20.

Groarke, Leo (1982). When two wrongs make a right. ILN 5:1, 10-13.

and Christopher Tindale (1985). Informal Logic: A Prolegomenon to Good Argument. Bristol. IN: Wyndham Hall Press.

(1986). Critical thinking: How to teach good reasoning. TP 9, 301-18.

Gronbeck, Bruce E. (1982). On classes of inference and force. In McKerrow 1982, 85-106.
(1989). Spheres of Argument: Proceedings of the 6th SCA/AFA Conference of Argumentation. Annadale, VA: Speech Communication Assoc.

Grootendorst, Rob (1987a). Everyday argumentation from a speech act perspective. In Wenzel et al. (1987a), 165-75

(1987b). Some fallacies about fallacies. In van Eemeren, Grootendorst, et al. (1987a), $33\lfloor-42$.

Gula, Robert J. (1979). Nonsense: How to Overcome It, New York: Stein and Day.

Gutenberg, Norbert (1987). Argumentation and dialectical logic. In van Eemeren, Grootendorst et al. $(1987 \mathrm{c}), 397-403$.

Gutteridge, Moira (1987). First, sit down and play the piano beautifully. IL 9, 81-91.

Haarscher, Guy (1979). La rhetorique de la raison pratique. Revue International de Philosophic $33,110-28$

Hallett, Garth J. (1984), Logic for the Labyrinth: A Guide to Critical Thinking. Lanham, MD: University Press of America.

Halpern, Diane F. (1984). Thought and Knowledge: An Introduction to Critical Thinking. Hillsdale, NJ: Lawrence Erlbaum.

Hamblin, Charles L. (1970). Fallacies. London: Methuen. Available from Newport News, VA: Vale Press.

Hample, Dale (1977). The Toulmin model and the syllogism. JAFA 14, 1-09.

(1980). A cognitive view of argument. JAFA 16, $151-58$.

(1982). Dual coding, reasoning and fallacies. JAFA $19,59-78$.

(1985). A third perspective on argumentation. $P \& R$ 18, 1-22.

(1988). Argument: Public and private, social and cognitive. Argumentation and $\mathrm{Ad}$ vocacy $25,13-19$.

Hample, Dale and Judith M. Dallinger (1984). Argument-as-Procedure and the Art of Controversy. Seattle, WA: Western Speech Communication Association.

(1987). Self-monitoring and the cognitive editing of arguments. Central States Speech Journal 38, 152-65. 
Hanson, Norwood R. (1967). The genetic fallacy revisited. American Philosophical Q. 4, 101-13.

Hardwig, John (1988). Relying on experts. In Govier (1988c), 125-37.

Harman. Gilbert (1984). Logic and reasoning. Synthese 60, 107-27.

(1986). Change in View: Principles of Reasoning. Cambridge, MA: MIT Press.

Harpine, William D. (1985). Can rhetoric and dialectic serve the purposes of logic? $P \& R 18$. 96-112.

Hayward, Albert (1986). Reconstructing arguments from editorials. TP 9, 61-70.

Healy, Paul (1987). Critical reasoning and dialectical argument: An extension of Toulmin's approach. $I L 9,1-12$.

Hepp. Maylon H. (1949). Thinking Things Through: An Introduction to Logic. New York: Charles Scribner's Sons.

Hinman, Lawrence (1982). The case for ad honinem arguments. Australasian $J$. of Philosophy 60, 338-45.

Hintikka, Jaakko (1973). Logic, Language-Games and Information. Oxford: Clarendon.

(1982). Game-theoretical semantics: Insights and prospects. Notre Dame J. of Formal Logic 23, 219-4!.

(1986). Logic of conversation as a logic of dialogue. In Richard Grandy (ed.), Philosophical Grounds of Rationality (Oxford: Oxford University Press). 1. 211-38

(1987a). The fallacy of fallacies. Arg.

(1987b). The interrogative approach to inquiry and probabilistic inference. Erkenntnis $26,429-42$.

(1989). The role of logic in argumen-

tation. Monist 72. 3-24.

and Merrill B. Hintikka (1982).

Sherlock Holmes confronts modern logic: Toward a theory of information-seeking through questions. In Barth and Martens (1982), $55-76$.

Hitchcock, David (1980). Deductive and inductive: Types of validity, not types of argument. $I L N$ $2: 3,9-10$.
(1981). Deduction, induction and conduction. ILN 3:2, 7-15.

(1983). Critical Thinking: A Guide to Evaluating Information. Toronto: Methuen.

7, 83-97

(1985). Enthymematic arguments. IL

(1986). Review of Walton's Topical Relevance in Argumentation. Dialogue 25, 819-21.

(1987). Enthymematic arguments. In van Eemeren, Grootendorst, et al. (1987a), 289-98.

Hoaglund, John (1983). Argumentum ad hominem: Aut bonum aut malum? ILN 4:3, 7-9.

(1984). Critical Thinking: An Introduction to Informal Logic. Newport News, VA: Vale Press.

(ed.) (1985). Conference ' 85 on Critical Thinking Newport News, VA: Christopher Newport College Press.

(1986a). A critical thinker abroad: Review of Schoberle's Argumentieren, Bewerten. Manipulieren. IL 8, 153-59.

(1986b). The logic of 'if-then' propositions. IL $8,141-50$.

(1986c). Typing. IL 8, 37-45.

(1989). 'Reasons' and premises. CT News $7: 4,1,7-8$.

Hoffman, Robert (1971). On begging the question at any time. Analysis 32, 51 .

Holland, J.H., J.K. Holyoak, R, E. Nisbett and P. Thagard (1986). Induction: Processes of Inference, Learning and Discovery. Cambridge, MA: MIT Press.

Hollinger, Robert (1985). Practical reasoning and hermeneutics. $P \& R \quad 18,113-22$.

House, Ernest R. (1977). The Logic of Evaluative Argument. Los Angeles: Center for the Study of Argumentation.

Hoven, P, J. van den (1987). The external justification of a dialectical concensus. In van Eemeren, Grootendorst et al. (1987c), 364-71.

Huber, Robert B. (1963). Influencing Through Argument. New York: David McKay.

Hufford, Roger (1965). The logician, the historian, and rhetorical criticism. JAFA 2, 14-16. 
Hurley, Patrick J. (1985). A Concise Introduction to Logic (2nd ed.). Belmont, CA: Wadsworth. 1st edition 1982.

Iseminger, Gary (1974). Succesful argument and rational belief. $P \& R 7,47-57$.

Jackson, Frank (1984). Petitio and the purpose of arguing. Pacific Philosophical Q. 65, 26-36.

Jackson, Sally (1985). What can speech acts do for argumentation theory? In Cox et al. (1985), $127-38$.

(1987). Rational and pragmatic aspects of argument. In van Eemeren, Grootendorst, et al. (1987a), 217-27.

(1989). What can argumentative practice tell us about argumentative norms? In Maier (1989), 113-22.

Jackson, Sally and Scott Jacobs (1981). The collaborative production of proposals in conversational argument and persuasion: A study of disagreement regulation. JAFA 18, 77-90.

Jackson, Sally, Scott Jacobs, Nancy Burrell and Mike Allen (1986). Characterizing ordinary arguments: Substantive and methodological issues. JAFA 23, 42-57.

Jacobs, Scott (1989). Some problems of communication for argumentation theory. ISSA Newsletter 5, 2-8.

(1989). Speech acts and arguments. Arg. 3, 345-65.

Jacques, Francis (1979). Logique ou rhetorique de l'argumentation? Revue International de Philosophic 33, 47-68.

Jacquette, Dale (1989). The hidden logic of slippery slope arguments. $P \& R 22,59-70$.

Jason, Gary (1984). Is there a case for ad hominem? Australasian $J$. of Philosophy 62, 182-85.

(1986). Are fallacies common? A look at two debates. IL 8, 81-92. Also in Govier (1988c), 20-34.

(1987). The nature of the argumentum ad baculum. Philosophia 17, 491-99.

(1988). Hedging as a fallacy of language. IL 10, 169-75. $101-06$.

(1989). Fallacies are common. IL 11 ,

Jensen, J. Vernon (1981). Argumentation: Reasoning in Communication. New York: D. Van Nostrand.
(1989). Bibliography on argumentation. Rhetoric Society Q. 19, 71-81.

Johnson, Baylor (1980). The Bask program. ILN 2:3, 16-18.

Johnson, Fred (1980). Deductively-inductively. ILN 3:1, 4-5. 26-27

(1984). Arguings and argument. IL 6 ,

(1989). Analogical arguings and explainings. IL 11, 153-60.

Johnson, Oliver A. (1967-68). Begging the question. Dialogue 6, 135-50.

Johnson, Ralph H. (1981a). Charity begins at home. ILN 3:3, 4-9.

(1981b). Reply to Griffin. ILN 4:1, 7 .

(1981c). The new logic course: The state of the art in non-formal methods of argument analysis. TP 4, 123-43.

(1981d). Toulmin's bold experiment:

Part I. ILN 3:2, 16-27.

(1981e). Toulmin's bold experiment:

Part II. ILN 3:3, 13-19.

(1982). Charity again. ILN 4:2, 16-17.

(1987a). Logic naturalized: Recovering a tradition. In van Eemeren, Grootendorst et al. $(1987 \mathrm{a}), 47-56$.

(1987b). The blaze of her splendours: Suggestions about revitalizing fallacy theory. Arg. 1, 239-53.

(1988a). Critical notice of Gilbert Harman's Change in View: Principles of Reasoning. Canadian J. of Philosophy 18, 163-78.

(1988b). Poll-ution: Coping with surveys and polls. In Govier (1988c), 163-77.

(1989). Massey on fallacy and informal logic: A reply. Synthese $80,407-26$.

(1990a). Acceptance is not enough: A critique of Hamblin. P\&R 23, 271-87.

$(1990 \mathrm{~b})$. Hamblin on the standard treatment. P\&R 23, 153-67.

Johnson, Ralph H. and J. Anthony Blair (1980a). A bibliography of recent work in informal logic. In Blair and Johnson (1980), 163-72.

(1980b). The recent development of informal logic. In Blair and Johnson (1980), 3-28.

(1983a). A bibliography of recent work in informal logic. ILN 5:3, 3-15. 
Johnson, Ralph H. and J. Anthony Blair (1983b). Logical Self-Defense (2nd ed.). Toronto: McGraw-Hill Ryerson. Ist edition 1977.

(1985a). Informal Logic: A journal for teachers of critical thinking. Newsletter on Teaching Philosophy, 14-16.

(1985b). Informal logic: The past five years 1978-83. American Philosophical Q. 22, $181-96$

(1989). The fallacy approach to criticizing arguments. In Maimon et al. (1989), 111-23.

Johnstone. Jr, Henry W. (1952). Philosophy and argumentum ad hominem. J. of Philosophy 49 , $489-98$.

(1959). Philosophy and Argument. University Park, PA: Pennsylvania State University Press.

(1970). 'Philosophy and argumentum ad hominem' revisited. Revue International de Philosophie 24, 107-116.

(1978). Validity and Rhetoric in Philosophical Argument: An Outlook in Transition. University Park, PA: The Dialogue Press of Man and World.

(1983). Truth, anagnorisis and argument. P\&R 16, 1-15. $129-134$

(1987). Response to Arnold. P\&R 20.

(1989). Argumentation and formal logic in philosophy, Arg. 3, 5-15.

Jones. Royce (1981). A new classification of disputes. TP 4, 23-32.

Kahane, Howard (1980). The nature and classification of fallacies. In Blair and Johnson (1980). 31-39.

(1984). John Nolt's inductive reasoning test. $I L 6,30$.

(1988). Logic and Contemporary Rhetoric, The Use of Reasoning in Everyday Life (5th ed.). Belmont. CA: Wadsworth Publishing Co. 1st edition 1971.

(1989). The proper subject matter for critical thinking courses. Arg. 3, 141-47.

Kasachkoff, Tziporah (1988), Explaining and justifying. IL 10, 21-30.

Kekes, John (1979). Perennial arguments, Idealistic Studies 9, 115-30.
Kellerman, Kathy (1980). The concept of evidence: A critical review. JAFA $16,159-72$.

Kelly, David (1988). The Art of Reasoning. New York: W. W. Norton and Co.

Kielkopf, Charles F. (1980), Relevant appeals to force, pity and popular pieties. ILN 2:2, $2-5$. 6. $21-25$.

(1984). Forms for 'informal logic'. IL

Kirby, Brian (1986). A plea for affirming a dis junct. $I L$ 8, 133-40.

Kirwan, Christopher (1979). Aristotle and the so-called fallacy of equivocation. Philosophical Q. 29, 35-46.

Kleiman, Lowell (1970). Pashman on Freud and the genetic fallacy. Southern J. of Philosophy $8,63-5$.

Kluback, William and Mortimer Becker (1979). The significance of Chaim Perelman's philosophy of rhetoric. Revue International de Philosophie 33, 31-46.

Klumpp, James F, Bernard L. Brook, James W. Chesebro and John F. Cragan (1974). Implications of a systems model of analysis on argumentation theory. JAFA 11, 1-7.

Kneupper, Charles W. (1978). On argument and diagrams. JAFA 14, 181-86.

(1979). Paradigms and problems: Alternative constructivist/interactionist implications for argumentation theory. JAFA 15. $220-27$.

(1980). Rhetoric, argument, and social reality: A social constructivist view. JAFA 16 , 173-81.

(1981). Argument: A social constructivist perspective. JAFA $17,183-89$.

Krabbe, Erik C. W. (1982). Theory of argumentation and the dialectical garb of formal logic. In Barth and Martens (1982), 123-32.

(1985). Formal systems of dialogue rules. Synthese 63, 295-328.

(1987). Naess's dichotomy of tenability and relevance. In van Eemeren et al. (1987a), 307-16.

(1988). Creative reasoning in formal discussion. Arg. 2, 483-98, 
Krabbe, Erik C. W. (1990). Inconsistent commitments and commitment to inconsistencies. $I L$ $12,33-42$.

Kroy. Moshe (1974). Logic, language and formalization. Logique et Analyse 17, 389-444.

Kruger, Arthur N. (1975). The nature of controversial statements. $P \& R 8,137-58$.

Kytle, Ray (1986). Clear Thinking for Composition (5th ed.). New York: Random House. Ist edition 1969.

La Bar, Carol and Ian Wright (1983). Practical Reasoning: Individual and Social Decision Making. Vancouver: U. of British Columbia, Faculty of Education.

and Jerrold Coombs (1982). First Steps in Practical Reasoning. Vancouver: U. of British Columbia, Faculty of Education.

Langsdorf, Lenore (1986). Is critical thinking a technique, or a means of enlightenment? IL 8 , $1-17$.

IL $9,117-24$.

(1988a). Dialogue, distanciation and engagement: Toward a theory of televisual communication. IL 10, 151-68.

(1988b). Ethical and logical analysis as human sciences. Human Studies 11, 43-63.

(1988c). Review of H. Siegel's Educating Reason. TP 11, 164-66.

(1990). On the uses of language in wotking and idealized logic. Arg 4, 259-68.

Largeault, J. (1978). De la difficulte d'expliquer ce qu'est la logique. Revue de Metaphysique et de Morale 82, 289-95.

Lavine, T. Z. (1962). Reflections on the genetic fallacy. Social Research 29, 321-36.

Leddy, Thomas (1986). Is there a fallacy of small sample? IL 8, 53-56.

Lee. Donald S. (1973). Assumption-seeking as hypothetic inference. P\&R 6, 13l-53.

Lehman, Darrin R., Richard O. Lempert and Richard E. Nisbett (1988). The effects of graduate training on reasoning: Formal discipline and thinking about everyday-life events. American Psychologist 43, 431-42.

Levi, Don S. (1987). In defense of informal logic. $P \& R 20,227-47$
Lipman, Matthew (1981). Why aren't reasoning skills being taught? Thinking $3,45-6$.

Little, J. Frederick (1980). Critical Thinking and Decision Making. Toronto: Butterworth.

Leo A. Groarke and Christopher W. Tindale (1989). Good Reasoning Matters. Toronto: McClelland and Stewart.

Lowery, Lawrence F. (1989). Thinking and Learning: Matching Developmental Stages With Curriculum and Instruction. Pacific Grove, CA: Midwest Publications

Lugenbehl, Dale E. (1985). Classroom logic terminology: Response to Seech. TP 8, 157-60.

Lugg, Andrew (1986). Deep disagreement and informal logic: No cause for alarm. IL 8, 47-51.

Lumer, Christoph (1988). The disputation: A special kind of co-operative argumentative dialogue. Arg. 2, $441-64$

Machina, Kenton F. (1985). Induction and deduction revisited. Nous 19, 571-578.

Mackenzie, Jim (1979). Question begging in noncumulative systems. I. of Philosophical Logic $8,117-33$

(1984a). Begging the question in dialogue. Australasian $J$. of Philosophy 62, 174-81.

(1984b). Confirmation of a conjecture of Peter of Spain concerning question-begging arguments. J. of Philosophical Logic 13, 35-45.

(1985). No logic before Friday. Synthese 63, 329-41.

(1988a). Authority. J. of the Philosophy of Education 22, 57-65.

(1988b). Distinguo: The response to equivocation. Arg. 2, 465-82.

(1988c). Woods on ideals of rationality in dialogue. Arg. 2, 409-17.

(1989). Reasoning and logic. Synthese $79,99-117$

Mackenzie, P. T. (1981). Ad hominem and ad verecundiam. ILN 3:3,9-11.

Mackie, John L. (1967). Fallacies. In Paul Edwards (ed.), Encyclopedia of Philosophy, 3. I69-79.

Mackinnon, Edward (1985). Basic Reasoning. Englewood Cliffs. NJ: Prentice-Hall. 
Mackinnon, Edward (1986). Practical reasoning and informal logic. $C T$ News 4:3, 1, 4-6.

Maier, Robert (1987). Cognitive development and fallacies. In van Eemeren, Grootendorst, et al. $(1987 \mathrm{~b}), 75-82$

(1989). Norms in Argumentation. Dordrecht: Foris.

Maimon, Elaine, Barbara Nodine and Finbarr O'Conner (eds.) (1989). Thinking, Reasoning and Writing. New York: Longmans.

Makau, Josina M. (1987). Perspectives on argumentation instruction. In van Eemeren and Grootendorst et al. (1987b), 376-85.

(1984). The Supreme Court and reasonableness. Quarterly $I$. of Speech 70, 379-96.

(1990). Reasoning and Communication: Thinking Critically About Arguments. Belmont, CA: Wadsworth.

Maker, William (1982). Teaching informal logic as emancipatory activity. ILN 5:1, 17-20.

Malone, Michael (1988). Review of Fisher's The Logic of Real Arguments. IL 10, 105-09.

Maneli, Mieczyslaw (1979). The new rhetoric and dialectics. Revue International de Philosophie $33,216-38$.

Manktelow, K. I. and D. E. Over (1987). Reasoning and rationality. Mind and Language 2, 199-219.

Mann, William C. (1988). Dialogue games: Conventions of human interaction, Arg. 2, 511-32.

Manning, Rita C. (1983a). A more charitable principle of charity. ILN 5:2, 20-21.

(1983b). Wright's Better Reasoning. ILN 5:2, 25-27.

Manor, Ruth (1982). Pragmatics and the logic of questions. Philosophica 29, 45-86. 3. $63-74$.

(1984). Dialogue representation. Topoi

Marks, Joel (1988). When is a fallacy not a fallacy? Metaphilosophy 19, 307-12.

Marlin, Randal (1984). The rhetoric of action description: Ambiguity in intensional reference. IL 6, 26-29.

Marshall, Ernest (1987). Formalism, fallacies, and the teaching of informal logic. In van Eemeren, Grootendorst et al. (1987b), 386-93.

Massey, Gerald (1975a). Are there any good arguments that bad arguments are bad? Philosophy in Context 4, 61-77.
Massey, Gerald (1975b). In defense of the assymetry. Philosophy in Context (Supplementary) 4, 44-56.

(1981a). The fallacy behind fallacies. Midwest Studies in Philosophy 6, 489-500. 303-36.

(1981b). The pedagogy of logic. TP 4 ,

Maxwell, Edwin A. (1959). Fallacies in Mathematics. Cambridge: Cambridge University Press.

May, John D. (1981). Practical reasoning: Extracting useful information from partial informants. $J$. of Pragmatics 5, 45-59.

(1986a). Journalistic sophistry, CT News $4: 4,1,5-7$.

(1986b). Journalistic sophistry. CT News 5:1, 1, 6-7.

(1988). Reportage as compound suggestion. IL 10, 113-31.

Mayer, Richard E. and Russell Revlin (1978). On information processing for research on human reasoning. In Russell Revlin and Richard E. Mayer (eds,), Human Reasoning (Washington, DC: Winston and Sons), 1-33.

McDonald, Daniel (1983). The Language of Argument (4th ed,). New York: Harper and Row.

McKerrow, Ray E. (1977). Rhetorical validity: An analysis of three perspectives on the justification of thetorical argument. JAFA 13 , $133-41$.

(1978). "Method of composition": Whately's earliest 'rhetoric'. $P \& R 11,43-58$.

(ed.) (1982). Explorations in Rhetoric: Studies in Honor of Douglas Ehninger Glenview, IL: Scott, Foresman.

McMurtry, John (1986). The argumentum ad adversarium. IL 8, 27-36.

(1988). The unspeakable: Understanding the system of fallacy in the media. IL $10,27-36$.

McPeck, John E. (1981a). Critical Thinking and Education. New York; St. Martin's

(1981b). Critical thinking without logic: Restoring dignity to information. Philosophy of Education: Proceedings 37, 219-27.

(1982). A second look at de Bono's heuristics for thinking. In William Maxwell (ed.), Thinking (Philadelphia: Franklin Institute Press), 163-76. 
McPeck, John E. (1984a). Stalking beasts but swatting flies: The teaching of critical thinking. Canadian $J$. of Education 9, 28-44.

(1984b). The evaluation of critical thinking programs: Dangers and dogmas. $I L, 6,9-13$.

(1985a). Critical thinking and the 'Trivial Pursuit' theory of knowledge. TP 8, 295-308.

(1985b). Paul's critique of Critical Thinking and Education. IL 7, 45-54.

(1985c). Response to H. Siegel's 'McPeck, informal logic and the nature of critical thinking'. Philosophy of Education: Proceedings $41,73-77$.

(1985d). Response to Norris's 'Thinking about critical thinking: Philosophers can't go it alone'. Philosophy of Education: Proceedings $41,89-96$.

(1987). Picture puzzles, red herrings, and geometry: Reply to R. Orton. Philosophy of Education: Proceedings 43, 303-07.

(1990) Teaching Critical Thinking: Dialogue and Dialectic. New York: Routledge, Chapman and Hall.

Measell, James S. (1985). Perelman on analogy. JAFA 22, 65-71.

Mechanic, Janevive Jean (1988). The Logic of Decision Making: An Introduction to Critical Thinking. New York: Lang.

Mechan, Eugene J. (1988). The Thinking Game, A Guide to Effective Study. Chatham, NJ: Chatham House Publishers.

Meiland, Jack W. (1981), College Thinking: How to Get the Best Out of College. New York: Mentor-New American.

(1989). Argument as inquiry and argument as persuasion. Arg. 3, 185-96.

Merrill, Kenneth R. (1982). A modest defense of 'bad old logic'. The New Scholasticism 56, 500-12.

Meyer, Michel (1979). Dialectique, rhetorique, hermeneutique et questionnement. Revue International de Philosophie 33, 145-77.

(1982). Argumentation in the light of a theory of questioning. $P \& R \quad 15,81-103$.

(1986). From Logic to Rhetoric. Amsterdam: John Benjamins.

(1988a). Questions and Questioning.

Berlin: Walter de Gruyter. (1988b). The rhetorical foundation of philosophical argumetation. Arg. 2, 255-69.

Michalos, Alex C. (1980). Advertising; Its logic, ethics and economics. In Blair and Johnson (1980), 93-111.

(1986). Improving Your Reasoning (2nd ed.). Englewood Cliffs, NJ: Prentice-Hall. 1st edition 1970.

Mieville, Denis (1989). Lorsque la logique rencontre l'argumentation. Arg. 3, 45-57.

Miller, Max (1987). Culture and collective argumentation. Arg. 1, 127-154.

Miller, Richard B. (1986). Toward an empirical definition of thinking skills. IL 8, 113-24.

Minkus, Peter A. (1980). Arguments that aren't arguments. In Blair and Johnson (1980), 69-76.

Minot, Walter S. (1981). A rhetorical view of fallacies: Ad hominem and ad populum. Rhetorical Society Q. 11, 222-35.

Missimer, Connie A. (1986). Good Arguments: An Introduction to Critical Thinking. Englewood Cliffs, NJ: Prentice-Hall. (1989a). Review of Costa and Lowery: Tochniques for Teaching Thinking. IL 11, 119-22. $7: 5,1,4-5$. (1989b). Types of evidence. CT News 145-57.

Mitroff, Ian (1982). On the structure of dialectical reasoning in the social and policy sciences. Theory and Decision 14, 331-50.

Moberg, Dale (1982). Apprasinig argumentative texts: Justificatory and defensive components. ILN 5:1, 20-23.

Moore, Brooke (1983). Critical thinking in California. TP 6, 321-330.

(1984). Critical reflection: Reply to Oscanyon. TP 7, 247.

and Richard Parker (1989). Critical Thinking: Evaluating Claims in Everyday Life (2nd ed.). Mountain View, CA: Mayfield Publishing Co. Ist edition 1986.

Moore, Kathleen D. (1987). A Field Guide to Inductive Arguments. Dubuque, IA: Kendall Hunt Publishing $\mathrm{Co}$.

Moore, W. Edgar, Janet McCann and Hugh McCann (1985). Creative and Critical Thinking ( 2 nd ed.). Boston: Houghton Mifflin Co. 1 st edition 1967. 
Mortensen, C. David and Ray Lynn Anderson (1970). The limits of logic. JAFA 7, 71-78.

Morton, Adam (1988). Making arguments explicit: The theoretical interest of practical difficulties. In Fisher (1988a), 65-77.

Mostowski, Marcin (1983). On empirical status of logical inferences. Bulletin of the Section of Logic 12, 181-87.

Mowry, David (1980). Informal logic and general education. ILN 2:2, 9-10.

Munson, Ronald (1976). The Way of Words: An Informal Logic. Boston: Houghton Mifflin.

Murnion. William (1986). The logic of learning. Philosophy Research Archives 12, $267-91$.

Myers, C. Mason (1978). Circular explication. Metaphilosophy 9, 1-13.

Naess, Arne (1966). Communication and Argument. London: Allen and Unwin.

Narveson, Jan (1980). Puzzle, ILN 1.2: A solution. ILN 2:3, 11 .

Natanson, Maurice and Henry W. Johnstone, Jr. (eds.) (1965). Philosophy, Rhetoric, and Argumentation. University Park, PA: The Penn State University Press.

Nelson, Beatrice Kapp (1980), Hierarchy, utility and fallacy in Bloom's taxonomy. Philosophy of Education: Proceedings 36, 260-68.

Nelson, John S., Alan Megill and Donald N. McClosky (eds.) (1987). The Rhetoric of the Human Sciences: Language and Argument in Scholarship and Public Affairs. Madison, WI: Univeristy of Wisconsin Press.

Nickerson, Raymond S., David Perkins and Edward E. Smith (1985). The Teaching of Thinking. Hillsdale, NJ: Lawrence Erlbaum.

Nielsen. Harry A. (1979). A note on the 'surprise test puzzle. ILN 2:1, 6-7.

Nisbett, Richard E. and Lee Ross (1980). Human Inference: Strategies and Shortcomings of Social Judgement. Englewood Cliffs, NJ: Prentice-Hall.

Nisbett, Richard E., Geoffrey T. Fong, Darrin R. Lehman and Patricia W. Cheng (1987). Teaching reasoning. Science 238, 625-31.

Nolen, Donald M. (1987). A critical theory of critical thinking. In van Eemeren and Grootendorst et al. (1987b), 349-57.

Nolt, John E. (1984a). Informal logic in China. IL $6,44-45$. (1984b). Informal Logic: Possible Worlds and Imagination. New York: McGrawHill Book Co.

$(1984 \mathrm{c})$. Possible worlds and imagination in informal logic. IL 6, 14-17.

(1985). More on induction and possible worlds: Replies to Thomas and Kahane. IL 7. $55-60$.

(1987). Dilemmas of the inductive/ deductive distinction. In van Eemeren, Grootendorst et al. $(1987 \mathrm{c}), 418-25$.

Noorden, Sally van (1979). Rhetorical arguments in Aristotle and Perelman. Revue International de Philosophie 33, 178-87.

Norris, Stephen P. (1985). Thinking about critical thinking: Philosophers can't go it alone. Philosophy of Education: Proceedings 41, 79-87.

Norris, Stephen P. and Robert H. Ennis (1989). Evaluating Critical Thinking. Pacific Grove. CA: Midwest Publications.

Norris, Stephen P. and Ruth King (1984a). Observation ability: Determining and extending its presence. IL 6, 3-9.

(1984b). The Design of a Critical Thinking Test on Appraising Observations. St. John's: Memorial University of Newfoundland.

Norris, Stephen P. and James Ryan (1987). Designing a test for inductive reasoning. In van Eemeren, Grootendorst, et al. (1987b), 394-403.

Nosich, Gerald M. (1982). Reasons and Arguments. Belmont, CA: Wadsworth.

O'Keefe, Daniel J. (1977). Two concepts of argument. JAFA 13, 121-28.

(1982). The concepts of argument and arguing. In Cox and Willard (1982) 3-23.

(1985). Argument criticism and Willardian skepticism. JAFA 21, 196-205.

Olbrechts-Tyteca, Lucie (1979), Les couples philosophiques: Une nouvelle approche. Revue International de Philosophie 33, 81-98.

and Evelyne Griffin-Collart (1979). Bibliographie de Chaim Perelman. Revue International de Philosophie 33, 325-42.

Oliver, James Willard (1967). Formal fallacies and other invalid arguments. Mind 76, 463-78.

Orr, Deborah (1989). Just the facts ma am: Informal logic, gender and pedagogy, IL 11, 1-10. 
Oscanyon, Frederick S, (1984), Critical thinking in California: Response to Brooke Moore. TP $7,241-47$.

Palmer, Humphrey (1981). Do circular arguments beg the question? Philosophy 56, 387-94.

Parker, Douglas H. (1972). Rhetoric, ethics and manipulation. P\&R 5, 69-87.

Parker, Richard A. (1984). Tu quoque arguments: A rhetorical perspective. JAFA 20, 123-32.

Parks-Clifford, J. E. (1990). Review of Moore and Parker's Critical Thinking: Evaluating Claims and Arguments in Everyday Life. IL 12, $113-16$.

Pashman, Jon (1970). Is the genetic fallacy a fallacy? Southern J. of Philosophy 8, 57-62.

(1971). Reply to Mr. Kleiman. Southern J. of Philosophy 9, 93-94.

Passmore, John (1963). Talking Things Over (3rd ed.). Melbourne: Melbourne University Press.

Paul, Richard W. (1982). Teaching critical thinking in the 'strong' sense. ILN 4:2, $2-7$.

(1983). An agenda item for the informal logic/critical thinking movement. ILN 5:2, 23-24.

(1985a). Background logic, critical thinking and irrational language games. $I L .7$, 9-18.

$35-43$

(1985b). McPeck's mistakes. IL 7 ,

(1989). Critical thinking in North America: A new theory of knowledge, learning and literacy. Arg. 3, 197-235.

(1990) Critical Thinking: What Every Person Needs to Survive in a Rapidly Changing World. A.J.A. Binker (ed.) Rohnert Park, CA: Center for Critical Thinking and Moral Critique.

Pecorino, Philip (1980). Exercise in argument construction using peer evaluation. ILN 2:3, 18 .

(1985). How does an informal logician analyse an argument? In Hoaglund (1985), 83-97.

(1987a). Critical thinking and philosophy. IL 9, 141-45.

(1987b). Critical thinking bibliography. APA Newsletter on Teaching Philosophy 87. 9, 125-29.
Peppinghaus, Benedikt (1976). Inadmissible arguments. Logique et Analyse 19, 119-38.

Perelman, Chaim (1963). The Idea of Justice and the Problem of Argument, John Petrie (trans.). London: Roulledge and Kegan Paul.

(1979a). La philosophie de pluralisme et la nouvelle rhetorique. Revue International de Philosophie 33, 5-17.

(1979b). The New Rhetoric and the Humanities: Essays on Rhetoric and Its Applications. W. Klubach (trans.) Dordrecht: Reidel Publishing Co.

(1980). Justice, Law and Argument: Essays on Moral and Legal Reasoning. Dordrecht: Reidell.

(1982). The Realm of Rhetoric, William Kluback (trans.). Notre Dame, IN: University of Notre Dame Press.

(1989). Rhetorique, Bruxelles: Editions de l'Universite de Bruxelles.

and L. Olbrechts-Tyteca (1969). The New Rhetoric: A Treatise on Argumentation, John Wilkinson and Purcell Weaver (trans.). Notre Dame, IN: University of Notre Dame Press. First published in 1958.

Perkins, David (1989). Reasoning as it is and could be: An empirical perspecitve. In D. N. Topping, D. C. Crowell, V. N. Kobayashi (eds.), Thinking Across Cultures (Hillsdale, NJ: Lawrence Erlbaum Associates), 175-94.

Petrie, Hugh G. (1969). Does logic have any relevance to argumentation? JAFA $6,55-60$.

Pinto, Robert C. (1984). Dialectic and the structure of argument. IL $6,16-20$.

Pirie, Madsen (1985). The Book of Fallacy: A Training Manual for Intellectual Subversives. London: Routledge and Kegan Paul.

Pole, Nelson (1981). Part/whole fallacies. ILN 3:3, 11-13.

Pomeroy, Ralph (1982). Ryle on (and for) informal logic. ILN 5:1, 23-25.

Porter, Thomas E. (1987). The Literate Mind: Reading, Writing, Critical Thinking. Dubuque, IA: Kendall/Hunt.

Prasad, Rajendra (1950). The Jaina conception of fallacies. Philosophical Quarterly (India) 23, 69-74.

Purtill, Richard L. (1972). Logical Thinking. New York: Harper and Row. 
Quine, W. V. and J. S. Ullian (1978). The Web of Belief (2nd ed.). New York: Random House. 1 st edition 1970.

Rancer, Andrew, Robert A. Baukus and Dominic A. Infante (1985). Relations between argumentativeness and belief structures about arguing. Communication Education 34, 211-220.

Ray, John W. (1978). Perelman's universal audience. Quarterly J. of Speech 64, 361-75.

Reboul, Olivier (1988). Can there be non-rhetorical argumentation? $P \& R 21,220-33$. Trans. by $\mathrm{H}$. W. Johnstone, Jr.

Reeder, Harry (1984). The nature of critical thinking. IL 6, 18-21.

Rees, M. Agnes Haft-Van (1989). Conversation, relevance, and argumentation. Arg. 3, 385-93.

Remland, Martin (1982). The implicit ad hominem fallacy: Nonverbal displays of status in argumentative discourse. JAFA 19, 79-86.

Rescher, Nicholas (1976). Plausible Reasoning: An Introduction to the Theory and Practice of Plausible Inference. Assen: Van Gorcum.

(1977). Dialectics: A ControversyOriented Approach to the Theory of Knowledge. Albany, NY: State University of New York Press.

(1987). How serious a fallacy is inconsistency? Arg. 1, 303-16.

Resnick. Lauren B. (1987). Education and Learning to Think. Washington, DC: National Academy Press.

Resnik, Michael D. (1985). Logic: Normative or descriptive: The ethics of belief or a branch of psychology. Philosophy of Science 52, 221-238.

Revlin, Russell and Von Otto Leirer (1978). The effects of personal biases on syllogistical reasoning: Rational decision from personalized representations. In Russell Revlin and Richard E. Mayer (eds.), Human Reasoning (Washington DC: Winston and Sons), 51-81.

Ricci. Paul O. (1986). Fundamentals of Critical Thinking. Lexington, MA: Ginn Press.

Richards, Thomas J. (1980). The fourth 'R'Reasoning. Australian Logic Teachers Journal 4. 1-10.

2-7.

(1981). Attitudes to reasoning. ILN 3:2,

Rieke, Richard D. and Malcolm O. Sillars (1984). Argumentation and the Decision Making Process. New York: John Wiley and Sons. 1st edition 1975
Riepe, Dale (1966). Some reconsiderations of the argumentum ad hominem. Darshana International $6,44-47$.

Robinet, A. (1979). Nouvelle rhetorique et informatique: Le pouvoir dialectique. Revue International de Philosophie 33, 129-44.

Robinson, Richard (1971a). Arguing from ignorance. Philosophical Quarterly 21, 97-108.

(1971b). Begging the question, 1971. Analysis 31, 113-17.

(1981). Begging the question, 1981 Analysis 41, 65.

Roblin, Ronald (1983). Review of Copi's Introduction to Logic, 6th ed. ILN 4:3, 12-13.

Rohatyn, Dennis (1987). When is a fallacy a fallacy? In van Eemeren, Grootendorst, et al. (1987b), 45-55.

(1988). The fallacies of doublespeak. CT News 6:4, 1, 3-4.

Ross, Gregory and George Semb (1981). Philosophy can teach critical thinking. TP 4, 111-22.

Rossie, Jean-Gerard (1973). Review of Toulmin's The Uses of Argument. Archiv fur Geschichte der Philosophic 55, 91-95.

Rothbart, Daniel (1983). Towards a structural analysis of extended arguments. ILN 5:2, 15-19.

Rottenberg, Annette T. (1985). Elements of Argument: A Text and Reader. New York: St. Martin's Press.

Rowe, William L. (1962). The fallacy of composition. Mind 71, 87-92.

Rowland, Robert C. (1984a). A response to Ulrich. JAFA 21, 94-96.

(1984b). Tabula Rasa: The relevance of debate to argumentation theory. JAFA 21, 76-88.

(1985). On argument evaluation. JAFA $21,123-32$. $140-59$.

(1987). On defining argument. $P \& R 20$,

Ruby, Lionel (1974). The Art of Making Sense: A Guide to Logical Thinking (3rd ed.). New York: J. B. Lippincott. 3rd edition revised by R. E. Yarber. 1st edition 1954.

Ruchlis, Hy (1990) Clear Thinking: A Practical Introduction (2nd ed.). Buffalo: Prometheus. 1st edition (1962) New York: Harper and Row. 
Ruggiero, Vincent Ryan (1988). The Art of Thinking: A Guide to Critical and Creative Thought (2nd ed.). New York: Harper and Row. Ist edition 1984

Runkle, Gerald (1981), Good Thinking: An Introduction to Logic ( 2 nd ed.). New York: Holt. Rinehart and Winston. 1st edition 1978.

Russell, Bertrand (1923). Vagueness. Australasian J. of Psychology and Philosophy 1, 84-92.

Russow, Lilly-Marlene (1989). Principles of Reasoning. New York: St. Martin's Press.

Ryle, Gilbert (1969). Formal and informal logic. In Dilemmas (Cambridge: Cambridge University Press), 111-29.

Saksteder, William (1974). The logic of analogy. $P \& R$ 7, 234-52.

(1979). Analogy; Justification for logic. P\&R 12, 21-40.

Salmon, Merrilee (1989). Introduction to Logic and Critical Thinking (2nd ed.). New York; Harcourt Brace Jovanovich. 1st edition 1984.

Salmon, Wesley (198I). In praise of relevance. $T P$ $4,261-75$.

(1984). Logic (3rd ed.). Englewood Cliffs, NJ: Prentice-Hall. Ist edition 1963.

Sanford, David (1972). Begging the question. Analysis 32, 197-99.

(1977). The fallacy of begging the question: A reply to Barker. Dialogue 16, 485-98.

(1981). Superfluous information, epistemic conditions of inference, and begging the question. Metaphilosophy 12, 145-58.

Schedler, George (1980). The argument from ignorance. International Logic Review 11, 66-71.

Scherer, Donald and Peter Facione (1977). A pre/post test for introductory logic courses. Metaphilosophy 8, 342-47.

Schmidt, Michael F. (1985). On anecdotes and axioms. CT News 4:2, 1, 4-5.

(1986a). Fallacies: A bibliography in progress. IL 8, 105-11.

(1986b). On classifications of fallacies. IL $8,57-66$.

Schwartz, Thomas (1980). The Ant of Logical Reasoning. New York: Random House. $231-47$

(1981). Logic as a liberal art. TP 4.
(1983). Logic and substance: A reply to Fogelin. ILN 4:3, 5-7.

(1984). Arguing for explanations: Logic and the special disciplines. IL 6, 10-15.

Scott, Robert L. (1987). Argument as critical art: Re-forming understanding. Arg. 1, 57-71.

Scriven, Michael (1970). Philosophy of education: Learning theory and teaching machines. $J$. of Philosophy 62, 896-908.

(1976). Reasoning. New York: McGraw-Hill. First published by Edgepress, Berkely, CA in 1976.

(1980). The philosophical and pragmatic significance of informal logic. In Blair and Johnson (1980), 147-60.

(1981) Evaluation Thesaurus, 3rd ed. Inverness, CA: Edgepress. Ist edition 1977.

(1984). Critical for survival. National Forum 65, 9-12.

(1987a). Critical thinking and the concept of literacy. IL 9, 93-110.

(1987b). Fallacies of statistical substitution. Arg. 1, 333-349.

(1987c). Probative logic. In van Eemeren, Grootendorst, et al. (1987a), 7-32.

(1987d). What are we doing? IL 9, 52 .

Scult, Allen (1985). A note on the range and utility of the universal audience. IAFA 22, 83-87.

Secor, Marie (1987). How common are fallacies? IL $9,41-48$.

Seech, Zachary (1981). RET: An informal method of evaluating reasoning. TP $4,145-50$.

(1987). Logic in Everyday Life: Practical Reasoning Skills. Belmont, CA: Wadsworth.

Semlak, William D. (1982). Argumentation and debate: A selected annotated bibliography. Distributed by SCCA Module-ERIC Clearing house on Reading and Communication skills.

Shaw, William H. and L. R. Ashley (1983). Analogy and inference. Dialogue 22, 415-32.

Shiner, Roger A. (1988). Ethical justification and case-by-case reasoning. In Douglas Odegard (ed.), Ethics and Justification (Edmonton: The Academic Press).

Siegel, Harvey (1980). Critical thinking as an educational ideal. Educational Forum 45, 7-23. 
Siegel, Harvey (1983). Psychology, epistemology and critical thinking. Philosophy of Education: Proceedings 39, 197-200

(1985a). Educating reason: Critical thinking, informal logic and the philosophy of education. IL 7, 69-81.

(1985b). McPeck, informal logic and the nature of critical thinking. Philosophy of Education: Proceedings 41, 61-72.

(1987). Skills, attitudes and education for critical thinking. In van Eemeren, Grootendorst, et al. (1987b), 358-65.

(1988). Educating Reason: Rationality, Critical Thinking and Education. New York: Routledge.

(1989a). Epistemology, critical thinking, and critical thinking pedagogy. Arg. 3, 127-40.

(1989b). The rationality of science, critical thinking, and science education. Synthese 80, 9-41.

(1989c). Why be rational? On thinking critically about critical thinking. Philosophy of Education: Proceedings 45, 392-401.

Simco, Nancy D, and Gene G. James (1976), Elementary Logic. Encino and Belmont: Dickenson.

Smiley. Timothy (1983). The schematic fallacy. Proceedings of the Aristotelian Society 83 $1-18$.

Smith, Joseph (1984). Formal logic: A degenerating research programme in crisis. Cogito 2, 1-18.

Smook, Roger (1988). Logical and extralogical constants. IL 10, 195-99.

Snoeyenbos, Milton H. (1980). Proofs and begging the question. ILN 3:1, 13.

Sorensen, Roy A. (1989). Slipping off the slippery slope: A reply to Professor Jacquette. $P \& R 22$, 195-202.

Spangler, G. A. (1983). Fogelin's Understanding Arguments. ILN 5:2, 27-30. $41-42$.

(1984). Reply to Fred Johnson. IL 6,

(1987). Review of Govier"s Practical Study of Argument. IL 9, 155-60.

Sparkes, A. W. (1966). Begging the question. $J$. of the History of Ideas 27, 462-63.
Sproule, J. Michael (1980). Argument: Language and Its Influence. New York: McGraw-Hill.

(1986). The roots of American argumentation theory: A review of landmark works, 1878-1932. JAFA 23, 110-15.

(1987). Ideology and critical thinking: The historical connection. JAFA 24, 4-15.

Suber, Peter (1990). A case study in ad hominem arguments: Fichte's Science of Knowledge. $P \& R 23,12-42$.

Swartz, Robert J. and D. N. Perkins (1989). Teaching Thinking: Issues and Approaches. Pacific Grove, CA: Midwest Publications.

Taba. Hilda (1979). The problem in developing critical thinking. Thinking 1, 77-79.

Taylor, William M. (1987). Teaching critical reading as a way of teaching critical thinking. IL 9, 111-15.

Thagard, Paul (1982). Fallacies of practical reasoning. ILN 5:1, 26-27.

Theron, Stephen (1988). Reality the measure of logic and not vice-versa. International Philosophical Q. 28, 185-92.

Thomas, Stephen N. (1984). Degrees of validity and ratios of conceivable worlds. $I L$ 6, 31-34.

(1986). Practical Reasoning in Natural Language (3rd ed.). Englewood Cliffs, NJ: Prentice-Hall. 1st edition 1973.

Thouless, Robert (1971). Straight and Crooked Thinking. London: Pan Books.

Tindale, Christopher and James Gough (1987). The use of irony in argumentation. $P \& R 20,1-17$.

Tindale, Christopher and Leo Groarke (1987). Logic and rhetoric: Groundwork for a synthesis. In van Eemeren, Grootendorst, et al. (1987c), 274-82.

Tomko, Thomas N. (1979). Informal logic: A Review. Educational Theory 29, 351-60.

(1981). Evaluation of formal logic competence. $T P$ 4, 145-50.

and Robert H. Ennis (1980). Evaluation of informal logic competence. In Blair and Johnson (1980), 113-44.

Toulmin, Stephen (1958). The Uses of Argument. Cambridge: Cambridge University Press.

Richard Rieke and Allan Janik (1984). An Introduction to Reasoning (2nd ed.). New York: Macmillan. Ist edition 1979. 
Trapp, Robert (1981). Special report on argumentation: Introduction. Western J. of Speech Communication $45,11-17$.

(1986). The role of disagreement in interactional argument. JAFA 23, 23-41.

(1987). Everyday argumentation from an interpretive perspective. In Wenzel (1987a), $185-90$.

(1987). On the characteristics of interactional argument: A response to Jackson, Jacobs, Burrell and Allen. JAFA 24, 63-72.

Trapp, Robert and Nancy Hoff (1985). A model of serial argument in interpersonal relationships. JAFA 22, 1-11.

Trapp, Robert and Janice Schuetz (1990). Perspectives on Argumentation. Essays in Honor of Wayne Brockreide. Prospect Heights, IL: Waveland Press.

Ulrich, Walter (1984), Debate as dialectic: A defense of the Tabula Rasa approach to judging. JAFA 21, 89-93.

(1985). In defense of the fallacy. In Cox et al. (1985), 110-126.

(1987). Argumentative validity as a function of the argumentative forum. In van Eemeren, Grootendorst, et al. (1987b), 7-16.

Vasoli, C. (1979). Topica, retorica, e argumentazione nelle "prima filosofia" del Vico. Revue International de Philosophie 33, 188-201.

Vate, Jr, Dwight van de (1975a). Reasoning and threatening: A reply to Yoos. $P \& R$ 8, 177-79. 43-60. (1975b). The appeal to force. $P \& R 8$,

Vedung, Evert (1982). Political Reasoning. Beverly Hills: Sage Publications.

(1983). Sytematic interpretation and the Principle of Charity. ILN 5:2, 21-22.

Verbiest, Agnes (1989). Confrontation in conversations: The adjacency pair as a tool of the descriptive component of a pragma-dialectical analysis. Arg. 3, 395-400.

Wagner, Paul (1987). Informing critical thinkers about cognitive science. Philosophy of Education: Proceedings 43, 179-83.

Walker, Gregg B. and Jeanine DiPaolo Congalton (1987), Generic argument and argument fields. JAFA 23, 125-35.
Walter, Bruce N. (1988). Critical Thinking: Consider the Verdict. Englewood Cliffs, NJ: Prentice-Hall.

Walters, Kerry S. (1989). On world views, commitment and critical thinking. IL $11,75-89$.

Walton, Douglas N. (1977). Mill and De Morgan on whether the syllogism is a petitio. International Logic Review 8, 57-68.

(1980a). Ignoratio elenchi: The Red Herring Fallacy. ILN 2:3, 3-7.

(1980b). Petitio principii and argument analysis. In Blair and Johnson (1980), 41-54.

(1980c). Why is the Ad Populum a fallacy? $P \& R$ 13, 264-78. Also in Woods and Walton (1989) 209-20.

(1981a). The fallacy of many questions. Logique et Analyse 24, 291-313. Also in Woods and Walton (1989) 233-51.

(1981b). What is logic about? ILN 4:1, 24 .

(1982). Topical Relevance in Argumentation. Amsterdam: John Benjamins.

(1984). Logical Dialogue-Games and Fallacies. Lanham, MD: University Press of America.

(1985a). Arguer's Position: A Pragmatic Study of 'Ad Hominem' Attack, Criticism, Refutation and Fallacy. Westport, CT: Greenwood Press.

(1985b). New directions in the logic of dialogue. Synthese 63, 259-74.

(1987a). Informal Fallacies: Towards a Theory of Argument Criticisms. Amsterdam: John Benjamins.

(1987b). The ad hominem argument as an informal fallacy. Arg. 1, 317-31.

(1987c). What is a fallacy? In van Eemeren, Grootendorst, et al. (1987a), 323-30.

(1988a). Argumentation and fallacies: The problem in teaching. In Venant Cauchy (ed.), Philosophy et Culture, 5 (Montreal: Editions Montmorency), 373-81 233-54.

(1988b). Burden of proof. Arg, 2,

$(1988 \mathrm{c})$. General bibliography on the argumentative structure of dialogue. Arg. 2, 533-34. 
Walton, Douglas N. (1989a). Dialogue theory for critical thinking. Arg. 3, 169-84.

(1989b). Informal Logic, A Handbook for Critical Argumentation. Cambridge: Cambridge University Press.

$(1989 \mathrm{c})$, Question-Reply Argumentation. New York: Greenwood Press.

(1989d). Reasoned use of expertise in argumentation. Arg. 3, 59-73.

(1990a). Practical Reasoning: Goal-

Driven, Knowledge-Based, Action-Guiding Argumentation. Savage, MD: Rowman and Littlefield.

(1990b). What is reasoning? What is an argument? J. of Philosophy 87, 399-419.

and L. M. Batten (1984). Games, graphs, and circular arguments. Logique et Analyse 27, 133-164.

Warren, Karen J. (1988). Critical thinking and feminism. IL $10,31-44$.

Weddle, Perry (1978). Argument: A Guide to Critical Thinking. New York: McGraw-Hill.

(1979). Inductive, deductive. ILN 2:1, 1-5.

(1980). Good Gricf! More on deductioninduction. ILN 3:1, 10-13.

(1984). McPeck's Critical Thinking and Education. IL 6. 23-25.

(1985a). Fact from opinion. IL 7 ,

19-26. Also in Govier (1988c), 65-72.

IL $7,119-26$.

(1985b). On theory in informal logic.

Weinstein, Mark (1982a). A role for formal logic in informal logic courses, ILN 4:2, 13-15.

(1982b). Musclebuilding for strength in critical thinking. ILN 5:1, 13-17.

(1985a). Formal logic revisited: The Lehman program. CT News 4:2, 1, 5-6.

(1985b). Philosophy and the general curriculum: The map of knowledge. Metaphilosphy 16, 239-49.

(1987). Reason and the theory of argument. In van Eemeren, Grootendorst, et al. $(1987 \mathrm{c}), 372-80$.

$10,1-20$. (1990a). Towards an account of argumentation in science. Arg 4, 269-98.

(1990b) Towards a research agenda for informal logic and critical thinking. IL 121-43.

Weiss, Stephen E. (1976). The sorites fallacy: What difference does a peanut make? Synthese $33,253-72$.

Weitzenfeld, Julian (1984). Valid reasoning by analogy, Philosophy of Science 51, 137-49.

Wellman, Carl (1971). Challenge and Response, Justification in Ethics. Carbondale, IL: University of Illinois.

Wenzel, Joseph W. (1977). Toward a rationale for value-centered argument. JAFA 13, 150-58.

(1979). Jurgen Habermas and the dialectical perspective on argumentation. JAFA 16 , $83-94$.

(1980). Perspectives on argument. In Jack Rhodes and Sarah Newell (eds.), Proceedings of the Summer Conference on Argumentation (Washington, D.C.: Speech Communication Association), 112-13.

(1982). On fields of argument as propositional systems. JAFA 18, 204-13.

(1985). Toward a normative theory of argumentation: Van Eemeren and Grootendorst's code of conduct for rational discussions. In Cox et al. (1985), 139-53.

(ed.) (1987a). Argument and Critical Practices: Proceedings of the Fifth SCA/AFA Conference on Argumentation, Annandale, VA: Speech Communication Assoc.

(1987b). The rhetorical perspective on argument. In van Eemeren, Grootendorst, et al. (1987a), 101-09.

$(1987 \mathrm{c})$. The rhetorical view of argumentation: Exploring a paradigm. Arg. 1, 73-88.

(1989). Relevance -and other norms of argumentation; A rhetorical exploration. In Maier (1989), 85-95.

Werkmeister, W. H. (1948). An Introduction to Critical Thinking: A Beginner's Text in Logic. Lincoln, NE: Johnson.

Weston, Anthony (1982). A pattern for argument analysis in informal logic. TP 5, 135-39.

(1987). A Rulebook for Arguments. Indianapolis, IN: Hackett. 
White, David (1985). Slippery slope arguments Metaphilosophy 16, 206-13.

Willard, Charles A. (1976). On the utility of descriptive diagrams for the analysis and criticism of arguments. Communication Monographs 43, 308-19.

(1978a). A reformulation of the concept of argument: The constructivist/interactionist foundations of a sociology of argument. JAFA $14,121-40$.

(1978b). Argument as non-discursive symbolism. JAFA 14, 187-93.

(1979a). The epistemic functions of argument: Reasoning and decision-making from a constructivist/interactionist point of view. Part 1. JAFA 15, 169-191.

(1979b). The epistemic functions of argument: Reasoning and decision-making from a constructivist/interactionist point of view. Part 2. JAFA 15, 211-19.

(1981a). Argument fields and theories of logical types. $J A F A \quad 17,129-45$.

(1981b). The status of the nondiscursiveness thesis. JAFA 17, 190-214.

(1983). Argumentation and the Social Grounds of Knowledge. Tuscaloosa, AL: University of Alabama Press. 206-14.

(1985). Reply to O'Kcefe. JAFA 21 ,

(1987). Valuing Dissensus. In van Eemeren, Grootendorst, et al. (1987a), 145-57.

(1989a). A Theory of Argumentation.

Tuscaloosa, AL: University of Alabama Press.

(1989b). Argument as a social process.

In Maier (1989), 161-77.

(1989c). The creation of publics: Notes on Goodnight's historical relativity. Argumentation and Advocacy 26, 45-59.

(1990a). Authority. IL 12, 11-22.

(1990b). The problem of the public sphere: Three diagnoses. In Williams ct al. (1990) 135-53.

Williams, David C. and Michael D. Hazen (eds.) (1990) Argumentation Theory and the Rhetoric of Assent. Tuscallosa, AL: U. of Alabama Press.

Williams, M. E. (1967-68). Begging the question? Dialogue 6, 567-70.

Wilson, Arnold (1985). Getting into an argument. IL 7, 63-64.
Wilson, Barbara and Edward S. Inch (1989). Critical Thinking and Communication: the Uses of Reason in Argument. New York: Macmillan.

Wilson, Barrie A. (1980). The Anatomy of Argument. Lanham, MD: University Press of America.

Wilson, John (1963). Thinking With Concepts. Cambridge: Cambridge University Press.

Windes, Russell R. and Arthur Hastings (1965). Argumentation and Advocacy. New York: Random House.

Winters, Barbara (1983). Inferring. Philosphical Studies 44, 201-20.

Wohlrapp, Harald (1987). Toulmin's theory and the dynamics of argumentation. In van Eemeren, Grootendorst et al. $(1987 \mathrm{c}), 327-35$.

Wolfe, Julian (1986), Inconsistency: A fallacy? IL $8,151-52$.

Woods, John (1980). What is informal logic? In Blair and Johnson (1980), 57-68. Also in Woods and Walton (1989) 221-32.

(1987a). Ad baculum, self-interest and Pascal's wager. In van Eemeren, Grootendorst, et al. (1987b), 343-349.

(1987b). Fallacies: Selected supplementary bibliography. Arg. 1, 351-53.

(1988a). Buttercups. GNP's and quarks: Are fallacies theoretical entities? IL 10, 67-76.

(1988b). Ideals of rationality in dialogue. Arg. 2, 395-408.

(1988c). Is philosophy progressive? Arg. 2, 157-74.

(1988d). Pragma-dialectics: A radical departure in fallacy theory, ISSA Newsletter 4 , 5-15.

(1988e). Rationality ideals and mentality. Arg. 2, 419-24.

(1989a). The maladroitness of epistemic TIT for TAT. I. of Philosophy 86, 324-31.

(1989b). The necessity of formalism in informal logic. Arg. 3, 149-67.

and Brent Hudak (1989). By parity of reasoning. IL. 11, 125-39.

Woods, John and Douglas N. Walton (1972). On fallacies. J. of Critical Analysis 4, 103-11. Also in Woods and Walton (1989) $1-10$.

(1974a). Argumentum ad verecundiam.

P\&R 7, 135-53. Also in Woods and Walton (1989) 11-28. 
Woods, John and Douglas N. Walton (1974b). Informal logic and critical thinking. Education 95, 84-86.

(1975a). Is the syllogism a petitio principii? The Mill News Letter 10, 13-15.

(1975b). Petitio principii. Synthese 31, 107-27. Also in Woods and Walton (1989) $29-45$.

(1976a). Ad baculum. Grazer Philosophische Studien 2, 133-40. Also in Woods and Walton (1989) 47-53.

(1976b). Ad hominem. Philosophical

Forum 8, 1-20. Also in Woods and Walton (1989) 55-73.

(1976c). Fallaciousness without invalidity? $P \& R$ 9, 52-54.

(1977a). Ad hominem, contra Gerber. The Personalist 58, 141-44. Also in Woods and Walton (1989) 87.91.

(1977b). Composition and division. Studia Logica 36, 381-406. Also in Woods and Walton (1989) 93-119.

$(1977 \mathrm{c})$. Petitio and relevant manypremissed arguments. Logique et Analyse 20, 97-110. Also in Woods and Walton (1989) 75-85.

(1977d). Post hoc, ergo propter hoc. Review of Metaphysics 30, 569-93. Also in Woods and Walton (1989) 121-141.

(1977e). Towards a theory of argument. Metaphilosophy 8, 298-315.

(1978a). Arresting circles in formal dialogues. J. of Philosophical Logic 7, 73-90. Also in Woods and Walton (1989) 143-59.

(1978b). The fallacy of ad ignorantiam. Dialectica 32, 87-99. Also in Woods and Walton (1989) 161-73.

(1979a). A brief guide to studying and teaching fallacies. Australian Logic Teachers Journal 3, 1-3.

(1979b). Equivocation and practical logic. Ratio 21, 31-43. Also in Woods and Walton (1989) 195-207.

$(1979 \mathrm{c})$. What type of argument is an ad verecundiam? ILN 2:1, 5-6. Also in Woods and Walton (1989) 191-94.

(1981). More on fallaciousness and invalidity. $P \& R \quad 14,168-72$. (1982a). Argument: The Logic of the Fallacies. Toronto: McGraw-Hill Ryerson.

(1982b). Question-begging and cumulativeness in dialectical games, Nous 16 , 585-605. Also in Woods and Walton (1989) 253-272.

(1982c). The Petitio: Aristotle's five ways. Canadian $J$. of Philosophy 12, 77-100.

(1989). Fallacies: Selected Papers 1972-82. Dordrecht: Foris.

Wreen, Michael J. (1987a). When no reason is good reason. In van Eemeren, Grootendorst, et al. $(1987 \mathrm{~b}), 56-64$.

(1987b). Yes, Virginia, there is a Santa Claus. IL 9, 31-39.

(1988a). Admit no force but argument. IL $10,89-95$.

(1988b). May the force be with you. Arg. 2, 425-40.

(1989). A bolt of fear. $P \& R 22,131-40$.

Wright, Ian and Carol La Bar (eds.) (1986). Critical Thinking and Social Studies Toronto: The History of Social Seience Teacher.

Wright, Larry (1982). Better Reasoning: Techniques for Handling Argument, Evidence and Abstraction. New York: Holt, Rinehart and Winston.

(1989). Practical Reasoning. San Diego, CA: Harcourt Brace Jovanovich.

Wright, Richard A. (1984). Logical Thinking: An Integrated Introduction. Englewood Cliffs, NJ: Prentice-Hall.

Wu, Kuand-Ming (1982). On playing with arguments. Southwest Philosophical Studies 7 , $58-67$.

Yanal, Robert J. (1988). Basic Logic. St. Paul, MN: West Publishing Co.

Yearly, Stephen (1988). Argumentation, epistemology and the sociology of language. Arg. 2, $351-67$.

Yoos, George (1975). A critique of van de Vate's 'The appeal to force'. $P \& R 8,172-76$.

(1984), Rhetoric, argument and logic. IL $6,10-16$.

(1987). The rhetoric of appeal and the rhetoric of response. $P \& R 20,107-17$.

(1988). Rheotric and "doing philosophy". Arg, 2, 191-207. 
Young, Gary (1974). Authority. Canadian J. of Philosophy 3, 563-83.

Zarefsky, David (1981). Review of Blair and Johnson's Informal Logic. JAFA 18, 64-67.

Malcolm O. Sillars and Jack Rhodes (eds.) (1983). Argument in Transition: Proceedings of the Third Summer Conference on Argumentation. Annandale, VA: SCA.
Ziegelmueller, George W. (1975). Argumentation Inquiry and Advocacy. Englewood Cliffs, NJ: Prentice-Hall.

and Jack Rhodes (eds.) (1981). Dimensions of Argument: Proceedings of the Second Summer Conference on Argumentation. Annandale, VA: SCA.

Zyskind, Harold (1979). The new rhetoric and formalism. Revue International de Philosophie 33, 18-32.

\section{Index to the Bibliography}

\section{Ad hominem and tu quoque arguments:}

E Barth, Martins 1977; A Brinton 1985; J Cragan, Cutbirth 1984; M Finocchiaro 1974; D Gerber 1974; D Gerber 1977; T Govier 1981c; T Govier 1983a; T Govier 1988d; L Hinman 1982; J Hoaglund 1983; G Jason 1984; H Johnstone, Jr. 1952; H Johnstone, Jr. 1970; P Mackenzie 1981; W Minot 1981; R Parker 1984; M Remland 1982; D Riepe 1966; P Suber 1990; D Walton 1985a; D Walton 1987b; J Woods, Walton 1976b; J Woods, Walton 1977a.

Ad verecundiam, arguments from authority:

W Benoit 1987; J Cederblom, Paulsen 1988; R Ennis 1974; J Hardwig 1988; J Mackenzie 1988a; D Walton 1989d; C Willard 1990a; J Woods, Walton 1979e; M Wreen 1987b; G Young 1974.

\section{'Ad' fallacies other than ad hominem and} ad verecundiam:

G Jason 1987; C Kielkopf 1980; J McMurtry 1986; D Vate, Jr. 1975a; D Vate, Jr. 1975b; D Walton 1980 c; J Woods 1987a; J Woods, Walton 1974a; J Woods, Walton 1976a; M Wreen 1988a; M Wreen 1988b; M Wreen 1989; G Yoos 1975.

All fallacies other than 'ad' fallacies and begging the question:

Y Bar-Hillel 1964; A Brinton 1988a; J Broyles 1975; J Cowan 1969; S Engel 1986a; F Fair 1973; L Feuer 1983; H Gelber 1987; T Goudge 1961; T Govier 1982a; L Groarke 1982; N Hanson 1967; D Jacquette 1989; G Jason 1988; C Kirwan 1979; L Kleiman 1970; T Lavine 1962; T Leddy 1986; J Mackenzie 1988b; J McMurtry 1988; J Pashman 1970; J Pashman 1971; N Pole 1981; N Rescher 1987; R Robinson 1971a; D Rohatyn 1988: W Rowe 1962; G Schedler 1980; M Scriven 1987b; T Smiley 1983; R Sorensen 1989; D Walton 1980a; D Walton 1981a; S Weiss 1976; D White 1985;
J Wolfe 1986; J Woods, Walton 1977b; J Woods, Walton 1977d; J Woods, Walton 1978b. J Woods, Walton $1979 \mathrm{~b}$.

\section{Analogical arguments:}

E Barker 1989; S Barker 1989; W Brown 1989; T Govier 1985; T Govier 1989a; F Johnson 1989; J Measell 1985; W Saksteder 1974; W Saksteder 1979; W Shaw, Ashley 1983; R Shiner 1988; J Weitzenfeld 1984; J Woods, Hudak 1989

\section{Argument evaluation:}

R Binkley 1981; M Black 1949; B Burleson 1979; S Campbell 1974; D Fischer 1970; T Govier 1980b; T Govier 1981a; W Grennan 1986; W Griffith 1975; G Iseminger 1974; R Johnson 1990a; R Johnson, Blair 1989; H Johnstone, Jr. 1983; H Kahane 1984; K Kellerman 1980; A Kruger 1975; G Massey 1975; G Massey 1975; E Maxwell 1959; A Michalos 1980; D Moberg 1982; D O'Keefe 1985; R Rowland 1985; Z Seech 1981; P Thagard 1982; M Wreen 1987a.

\section{Argument interpretation, the principle of charity:}

J Adler 1982; J Berg 1987; P Davson-Galle 1989; R Fogelin 1983; C Gauker 1986; T Govier 1981b; N Griffin 1981a; M Gutteridge 1987; D Hample 1977; D Hample, Dallinger 1987; A Hayward 1986; P Healy 1987; J Hoaglund 1986b; J Hoaglund 1986c; S Jackson, Jacobs, Burrell, Allen 1986; R Johnson 1981a; R Johnson 1981b; R Johnson 1981c; R Johnson 1982; C Kneupper 1978; R Manning 1983a: R Marlin 1984; J May 1981; A Morton 1988; P Pecorino 1985; D Rothbart 1983; T Schwartz 1983; C Tindale, Gough 1987; E Vedung 1983; A Verbiest 1989; A Weston 1982; C. Willard 1976; H Wohlrapp 1987.

Argumentation theory:

J Anderson, Dovre 1968; L Apostel 1971; L 
Apostel 1982; D Apotheloz 1987; C Arnold 1986; E Barth, Martins 1982; P Benoit 1989; J Blair 1987b; J Braaten 1987; W Brockriede 1972; G Brutian 1984; J Corcoran 1989; V Corgan 1987; R Crable 1976b; F Eemeren 1986; F Eemeren 1987a; F Eemeren 1987b; F Eemeren 1988; F Eemeren, Grootendorst 1982a; F Eemeren, Grootendorst 1984; F Eemeren, Grootendorst 1988a; F Eemeren, Grootendorst 1989a; F Eemeren, Grootendorst, Kruiger 1984; F Eemeren, Grootendorst, Kruiger 1987; F Eemeren, Grootendorst, Blair, Willard 1987a; F Eemeren, Grootendorst, Blair, Willard 1987b; F Eemeren, Grootendorst, Blair, Willard 1987c; D Ehninger 1980; E Feteris 1990; M Finocchiaro 1987a; S Fuller, Willard 1987; J Furlong 1987; G Goodnight 1989; T Govier 1987b; D Hample 1988; J Hintikka 1989; S Jackson 1985; S Jackson 1989; S Jacobs 1989; S Jacobs 1989; J Klumpp, Brook, Chesebro, Cragan 1974; C Kneupper 1979; L Langsdorf 1988a; L Langsdorf 1988b; R Maier 1989; M Maneli 1978; M Meyer 1986; M Meyer 1988a; D Mieville 1989; M Miller 1987; A Naess 1966; M Natanson, Johnstone, Jr. 1965; C Perelman 1963; S Toulmin 1958; R Trapp, Schuetz 1990; E Vedung 1982; M Weinstein 1987; C Wellman 1971; J Wenzel 1979; J Wenzel 1985; C Willard $1981 \mathrm{a} ; \mathrm{C}$ Willard 1981b; C Willard 1983; C Willard 1987; C Willard 1989a; C Willard 1989b; C Willard 1989c; C Willard 1990b; J Woods, Walton 1977e; S Yearly 1988.

\section{Arguments: Their nature and their analysis:}

R Anderson, Mortensen 1967; L Apostel 1979; S Bailin 1987; V Balthrop 1980; E Barth 1987; P Bator 1988; P Benoit 1983; D Bernstein 1990; J Bickenbach 1982; J Bickenbach 1990; J Blair 1987d; E Blythin 1979; W Brockriede 1975; W Brockriede 1977; W Brockriede 1985; W Brown 1987; M Bruner 1983; M Cohen 1977; R Corliss 1972; E Dayton 1981; F Eemeren, Grootendorst $1989 \mathrm{c}$; F Eemeren, Kruiger 1987; F Eemeren, Grootendorst, Meuffels 1989; D Ehninger 1970; M Finocchiaro 1979a; M Finocchiaro 1988c; A Fisher 1987; A Fisher 1989; R Fogelin 1985; V Follert 1981; J Freeman 1985; E Garver 1987; J Gasser 1987; J Golden, Makau 1982; A Goldman 1987; T Goode, Wettersten 1982; R Grootendorst 1987a; D Hample 1980; D Hample 1985; J Hoaglund 1989; S Jackson 1987; F Johnson 1984; R Jones 1981; C Kielkopf 1984; B Kirby 1986; C Kneupper 1981; A Lugg 1986; J Meiland 1981; J Meiland 1989; P Minkus 1980; D O'Keefe 1977; D O'Keefe 1982; P Pecorino 1980; A Rancer, Baukus, Infante 1985; J Ray 1978; R Rowland 1987; T Schwartz 1984; R Scott 1987; M Scriven 1987c; A Scult
1985; R Trapp 1986; R Trapp 1987; R Trapp 1987; R Trapp, Hoff 1985; G Walker, Congalton 1987; M Weinstein 1990a; J Wenzel 1977; J Wenzel 1980; J Wenzel 1982; C Willard 1978a; C Willard 1978b; C Willard 1979b; C Willard 1985; D Williams, Hazen 1990; K Wu 1982.

\section{Begging the question, petitio principii, circular arguments:}

J Barker 1976; J Barker 1978; D Basu 1986; J Biro 1977; J Biro 1984; G Colwell 1989; R Hoffman 1971; F Jackson 1984; O Johnson 1967-68; J Mackenzie 1979; J Mackenzie 1984a; J Mackenzie 1984b; C Myers 1978; H Palmer 1981; R Robinson 1971b; R Robinson 1981; D Sanford 1972; D Sanford 1977; D Sanford 1981; M Snoeyenbos 1980; A Sparkes 1966; D Walton 1977; D Walton 1980b; D Walton, Batten 1984; M Williams 1967-68; J Woods, Walton 1975a; J Woods, Walton 1975b; J Woods, Walton 1977c; J Woods, Walton 1978a; J Woods, Walton 1982b; J Woods, Walton $1982 \mathrm{c}$.

\section{Bibliographies;}

L Bomstad, Weddle 1989; C Champaud, Bassano 1987; R Church 1979; R Church, Buckley 1983; F Conklin 1968; F Conklin 1970; F Conklin 1971; R Cureton 1973; R Ennis 1987a; J Jensen 1989; R Johnson, Blair 1980a; R Johnson, Blair 1983a; L Olbrechis-Tyteca, Griffin-Collart 1979; P Pecorino 1987b; M Schmidt 1986a; W Semlak 1982; J Woods 1987b; D Walton 1988c.

\section{Critical thinking:}

J Adler 1987c; J Adler 1990b; D Annis, Annis 1979; L Annis, Annis 1984; S Bailin 1987; S Bailin 1989; M Battersby 1989; J Blair 1985; J Blair 1986b; J Blair 1987a; J Blair 1987e; J Blair 1988d; E d'Angelo 1974; R Ennis 1962; R Ennis 1964; R Ennis 1979; R Ennis 1980; R Ennis 1981b; R Ennis 1981c; R Ennis 1985; R Ennis 1987b; R Ennis 1989a; R Ennis 1989b; P Facione 1984; P Facione 1990a; M Finocchiaro 1988a; J Freeman 1989; T Govier 1983c; T Govier 1989b; J Hoaglund 1985; R Johnson 1988b; H Kahane 1989; L Langsdorf 1986; L Langsdorf 1987; J May 1986a; J May 1986b; J May 1988; J McPeck 1981a; J McPeck 1981b; J McPeck 1982; J McPeck 1984a; J McPeck 1985a; J McPeck 1985b; J McPeck 1985c; J McPeck 1985d; J McPeck 1987; R Miller 1986; C Missimer 1990; B Nelson 1980; D Nolen 1987; S Norris 1985; R Paul 1982; R Paul 1983; R Paul 1985a; R Paul 1985b; R Paul 1989; R Paul 1990; P Pecorino 1987a; H Reeder 1984; R Revlin, Leirer 1978; G Ross, Semb 1981; 
B Russell 1923; M Scriven 1984; M Scriven 1987a; H Siegel 1980; H Siegel 1983; H Siegel 1987; H Siegel 1988; H Siegel 1989a; H Siegel 1989b; H Siegel 1989c; J Sproule 1987; H Taba 1979; P Wagner 1987; K Walters 1989; K Warren 1988; P Weddle 1985a; $\mathrm{M}$ Weinstein 1982b; M Weinstein 1988; I Wright, La Bar 1986.

\section{Deduction, conduction, induction:}

J Bickenbach 1979; G Englebretsen 1984; S Fohr 1980a; S Fohr 1980b; J Freeman 1983; J Freeman 1984; T Govier 1980c; T Govier 1987a; D Hitchcock 1980; D Hitchcock 1981: J Holland, Holyoak. Nisbett, Thagard 1986; F Johnson 1980; K Machina 1985; J Nolt 1984c; J Nolt 1985; J Nolt 1987; G Spangler 1984; P Weddle 1979; P Weddle 1980 .

\section{Dialogic, dialogue games, the logic of} questions:

E Barth 1985c; E Barth, Krabbe 1982; I Bendegem 1985; J Blair 1986a; J Blair, Johnson 1987a; R Brown 1970; L Carlson 1983; F Damme 1984; F Eemeren, Grootendorst 1988b; M Finocchiaro 1988b; N Gutenberg 1987; J Hintikka 1973; J Hintikka 1982; J Hintikka 1986; J Hintikka 1987b; J Hintikka, Hintikka 1982; P Hoven 1987; E Krabbe 1982; E Krabbe 1985; C Lumer 1988; J Mackenzie 1988c; W Mann 1988; R Manor 1982; R Manor 1984; M Meyer 1979; M Meyer 1982; I Mitroff 1982; R Pinto 1984; N Rescher 1977; A Robinet 1979; W Ulrich 1984; D Walton 1984; D Watton 1985b; D Walton 1988b; D Walton 1989a; D Walton 1989c; J Woods 1988b.

\section{Fallacy theory; nature of and classification} of fallacies:

C Abate 1979; L Apostel 1971; J Biro 1987; J Blair 1988a; J Blair 1990; C Broad 1950; R Carroll 1983; F Cizek 1974; R Cole 1965; J Cox, Willard 1982; F Eemeren, Grootendorst 1987a; F Eemeren, Grootendorst 1989b; S Engel 1986b; S Engel 1986c; P Facione 1987; M Finocchiaro 1981; M Finocchiaro 1987b; R Fogelin, Duggan 1987; R George 1983a; I Good 1959; T Govier 1982b; R Grootendorst 1987b; C Hamblin 1970; D Hample 1982; J Hintikka 1987a; G Jason 1986; G Jason 1989; R Johnson 1987b; R Johnson 1989; R Johnson 1990b; H Kahane 1980; J Mackie 1967; R Maier 1987; J Marks 1988; E Marshall 1987; G Massey 1981a; J Oliver 1967; R Prasad 1950; D Rohatyn 1987; R Rowland 1984b; M Schmidt 1986b; M Secor 1987; W Ulrich 1985; D Walton 1987a; J Woods 1988a; J Woods 1988d; J Woods, Walton 1972; J Woods, Walton 1976c; J Woods,
Walton 1981; J Woods, Walton 1982a; J Woods, Walton 1989.

\section{Formal and informal logic:}

B Aune 1986; E Barth 1990; S Doss 1985; S Doss 1989; R Girle 1988; T Govier 1982b; M Kroy 1974; I Largeault 1978; D Levi 1987; K Merrill 1982; H Petrie 1969; R Pomeroy 1982; G Ryle 1969; M Scriven 1980; J Smith 1984; D Walton 1981b; D Walton 1987c: P Weddle 1985b; M Weinstein 1982a; M Weinstein 1985a; J Woods 1980; J Woods $1989 \mathrm{~b}$.

Histories, surveys, reports, state of the art:

E Barth 1985b; J Blair, Johnson 1987b; A Fisher 1986; R Johnson, Blair 1980b; R Johnson, Blair 1985a; R Johnson, Blair 1985b; B Moore 1983; B Moore 1984; J Nolt 1984a; F Oscanyon 1984; J Sproule 1986; T Tomko 1979; R Trapp 1981.

\section{Inference norms:}

J Adler 1989; D Allen 1988; K Bach 1984; E Krabbe 1987; C Missimer 1989b; S Thomas 1984; W Ulrich 1987.

\section{Informal logic and critical thinking:}

J Blair 1988b; J Blair, Johnson 1989; A Fisher 1988a; W Fisher 1978; W Fisher 1987; W Fisher 1980; L Langsdorf 1990; E MacKinnon 1986; D Orr 1989; M Scriven 1987d; H Siegel 1985a; H Siegel 1985b; M Weinstein 1990b; J Woods, Walton $1974 \mathrm{~b}$.

\section{Logic, reasoning and inference:}

M Black 1963; L Cohen 1982; M Finocchiaro 1979b; M Finocchiaro 1984; L Goldstein 1988; P Goodwin, Wenzel 1979; E Griffin-Collart 1979; B Gronbeck 1982; G Harman 1984; G Harman 1986; R Johnson 1988a; E Krabbe 1988; J Mackenzie 1989; K Manktelow, Over 1987; M Mostowski 1983; R Nisbett, Ross 1980; C Perelman 1980; D Perkins 1989; N Rescher 1976; M Resnik 1985; D Walton 1990a; D Walton 1990b; B Winters 1983.

Missing, hidden, unexpressed premises; assumptions, enthymemes:

E Brandon 1986; M Burke 1985; S Carey 1988; T Conley 1984; E d'Angelo 1974; M Donn 1990; F Eemeren, Grootendorst 1982b; F Eemeren, Grootendorst 1983; R Ennis 1981b; R Ennis 1982; R George 1983b; J Gough, Tindale 1985; D Goulding 1965; D Hitchcock 1985; D Hitchcock 1987; D Lee 1973. 


\section{Pedagogy: Teaching and testing:}

W Benoit, Follert 1986; A Binker, Charbonneau 1983; R Binkley 1980; J Blair 1984; J Blair 1988c; E Brandon 1987; A Brinton 1981; D Clemens 1985; A Costa, Lowery 1989; D Couch 1981; P Covey 1981a; P Covey 1981b; H Crimmel 1980; H Crimmel 1981; F Eemeren. Grootendorst 1987b; R Ennis 1958; R Ennis 1981a; R Ennis 1984; R Ennis 1987c; J Evra 1985; P Facione 1986; P Facione 1989: P Facione 1990b; J Follman 1987; E Garver 1985; L Gibbs 1985; T Govier 1988b; T Govier 1988e; L Groarke, Tindale 1986; B Johnson 1980; D Lehman, Lempert, Nisbett 1988; M Lipman 1981; L Lowery 1989; D Lugenbehl 1985; J Makau 1987; W Maker 1982; G Massey 1981b; J McPeck 1984b; J McPeck 1990; D Mowry 1980; R Nickerson, Perkins, Smith 1985; R Nisbett, Fong, Lehman, Cheng 1987; S Norris, Ennis 1989; S Norris, King 1984a; S Norris, King 1984b; S Norris, Ryan 1987; P Pecorino 1987c; L Resnick 1987; T Richards 1980; T Richards 1981; D Scherer, Facione 1977; T Schwartz 1981; R Swartz, Perkins 1989; W Taylor 1987; T Tomko 1981; T Tomko, Ennis 1980; D Walton 1988a; M Weinstein 1985b; A Wilson 1985; J Woods, Walton 1979a.

\section{Relevance:}

N Belnap 1981; J Blair 1989; G Bowles 1989a;
G Bowles 1990; E Garver 1978; M Rees 1989; W Salmon 1981; D Walton 1982; J Wenzel 1989.

The rhetorical dimension:

C Arnold 1987; M Beardsley 1981; G Bouchard 1981; A Brinton 1986; A Brinton 1987; A Brinton 1988b; R Burke 1984; T Farrell 1977; S Foss, Foss, Trapp 1985; E Garver 1978; J Golden 1987; G Haarscher 1979; W Harpine 1985; R Hufford 1965; F Jacques 1979; W Kluback, Becker 1979; C Kneupper 1980; M Maneli 1979; R McKerrow 1977; R McKerrow 1978; R McKerrow 1982; M Meyer 1988b; J Nelson, Megill, McClosky 1987; S Noorden 1979; L OlbrechtsTyteca 1979; D Parker 1972; C Perelman 1979a; C Perelman 1979b; C Perelman 1982; C Perelman 1989; C Perelman, Olbrechts-Tyteca 1969; O Reboul 1988; C Tindale, Groarke 1987; C Vasoli 1979; J Wenzel 1987b; J Wenzel 1987c; G Yoos 1984; G Yoos 1987; G Yoos 1988; H Zyskind 1979.
HANS V. HANSEN
184 GENEVA STREET
ST. CATHARINES
ONTARIO L2R 4 P5 